\title{
Potentials, Limitations, Co-Benefits, and Trade-Offs of Biochar Applications to Soils for Climate Change Mitigation
}

\author{
Alexandre Tisserant * and Francesco Cherubini \\ Industrial Ecology Programme, Department of Energy and Process Engineering, Norwegian University of \\ Science and Technology (NTNU), NO-7034 Trondheim, Norway; francesco.cherubini@ntnu.no \\ * Correspondence: alexandre.tisserant@ntnu.no; Tel.: +47-94163732
}

Received: 31 October 2019; Accepted: 20 November 2019; Published: 23 November 2019

\begin{abstract}
Biochar is one of the most affordable negative emission technologies (NET) at hand for future large-scale deployment of carbon dioxide removal (CDR), which is typically found essential to stabilizing global temperature rise at relatively low levels. Biochar has also attracted attention as a soil amendment capable of improving yield and soil quality and of reducing soil greenhouse gas (GHG) emissions. In this work, we review the literature on biochar production potential and its effects on climate, food security, ecosystems, and toxicity. We identify three key factors that are largely affecting the environmental performance of biochar application to agricultural soils: (1) production condition during pyrolysis, (2) soil conditions and background climate, and (3) field management of biochar. Biochar production using only forest or crop residues can achieve up to $10 \%$ of the required CDR for $1.5{ }^{\circ} \mathrm{C}$ pathways and about $25 \%$ for $2{ }^{\circ} \mathrm{C}$ pathways; the consideration of dedicated crops as biochar feedstocks increases the CDR potential up to $15-35 \%$ and $35-50 \%$, respectively. A quantitative review of life-cycle assessment (LCA) studies of biochar systems shows that the total climate change assessment of biochar ranges between a net emission of $0.04 \mathrm{tCO}_{2} \mathrm{eq}$ and a net reduction of $1.67 \mathrm{tCO}_{2}$ eq per tonnes feedstock. The wide range of values is due to different assumptions in the LCA studies, such as type of feedstock, biochar stability in soils, soil emissions, substitution effects, and methodological issues. Potential trade-offs between climate mitigation and other environmental impact categories include particulate matter, acidification, and eutrophication and mostly depend on the background energy system considered and on whether residues or dedicated feedstocks are used for biochar production. Overall, our review finds that biochar in soils presents relatively low risks in terms of negative environmental impacts and can improve soil quality and that decisions regarding feedstock mix and pyrolysis conditions can be optimized to maximize climate benefits and to reduce trade-offs under different soil conditions. However, more knowledge on the fate of biochar in freshwater systems and as black carbon emissions is required, as they represent potential negative consequences for climate and toxicity. Biochar systems also interact with the climate through many complex mechanisms (i.e., surface albedo, black carbon emissions from soils, etc.) or with water bodies through leaching of nutrients. These effects are complex and the lack of simplified metrics and approaches prevents their routine inclusion in environmental assessment studies. Specific emission factors produced from more sophisticated climate and ecosystem models are instrumental to increasing the resolution and accuracy of environmental sustainability analysis of biochar systems and can ultimately improve the characterization of the heterogeneities of varying local conditions and combinations of type feedstock, conversion process, soil conditions, and application practice.
\end{abstract}


Keywords: biochar; pyrolysis; food security; climate mitigation; negative emission technology; carbon dioxide removal; life-cycle assessment; environmental assessment; biogeochemical cycles; biophysical effects

\section{Introduction}

Human activities affect the earth system globally, pushing on some planet boundaries [1]. Crossing the boundary for climate change is a major concern as global climate feedbacks could push toward a "Hothouse Earth" pathway and could deeply affect the biosphere and society globally [2]. For this reason, the Paris agreement states the goal of "Holding the increase in the global average temperature to well below $2{ }^{\circ} \mathrm{C}$ above preindustrial levels and pursuing efforts to limit the temperature increase to $1.5^{\circ} \mathrm{C}^{\prime \prime}[3]$.

Reaching the Paris agreement is challenging as some economic sectors are hard to decarbonize (e.g., transportation) or are subject to lock-in (e.g., lifetime of power plants). Capture of carbon from the atmosphere or at the plant will be required to offset unavoidable emissions. Inertia in transforming the economic system will likely lead to an overshoot of the Paris target, and atmospheric capture of carbon will be required during a period of net negative emissions to lower back temperature by 2100 . Even under scenario pathways of lifestyle changes and faster deployment of renewable electrification, net negative emissions are required [4].

Several negative emission technologies (NET) for carbon dioxide removal (CDR) are discussed in the literature: afforestation and reforestation, bioenergy with carbon capture and storage (BECCS), biochar, enhanced weathering, soil carbon sequestration, ocean fertilization, and direct air capture (DACCS) [5]. Several of them raise concerns regarding energy requirements, land competition, toxicity, and potential unexplored long-term consequences [5-8].

Biochar [9] emerged in the recent years as a win-win option that can act both as a carbon sink and as an amendment improving soil quality, increase fertility, and water holding capacity, thereby preventing risks for land degradation [10]. Production of biochar occurs via a thermochemical process called pyrolysis. Pyrolysis is the thermal decomposition of biomass at high temperature and in the absence of or under very low oxygen concentration and is associated with the production of three by-products: biochar (solid), bio-oil (liquid), and syngas (gas).

Biochar production and application to agricultural soils interact with the environment and climate system in multiple complex ways. There are emissions from feedstock collection, transport, and biochar production via pyrolysis, and biochar applications affect soil emission balance (e.g., $\mathrm{N}_{2} \mathrm{O}$, $\mathrm{CH}_{4}, \mathrm{NH}_{3}$, and $\mathrm{NO}_{x}$ ). Biochar also influences the climate system by complex mechanisms, including the long-term storage of biogenic carbon in soils and changing soil reflectivity (e.g., albedo) by darkening the surface. All these aspects are relevant for environmental assessment of climate change, eutrophication, acidification, and human health, for example.

There are many existing review studies on biochar, but studies that include this variety of factors in an integrated framework are rare or only includes some of them [11-15]. An increasing number of studies assesses the role of biochar as a negative emissions technology, with a quantification of technical, economic, and sustainable large-scale deployment potential $[5,14,16,17]$. Individual studies focus on different aspects of its production systems and on one or more environmental implication(s), such as the long-term stability and effect on soil organic carbon (SOC) [18-21], its effect on soil physical and hydraulic properties [22-25], soil degradation [26,27], agricultural yield [28-32], greenhouse gas balance (GHG) [33-44], nitrogen availability and emissions [37-40,45-47], that of phosphorus [48-50], biochar's toxicity [51-53], remediation potential [54-59], and effects on pesticides [60-62]. These review studies generally show that the type of biomass feedstock, biochar production conditions, local soil properties, and management decisions all modulate soil and environmental responses after biochar 
production and application and that undesired outcomes in terms of environmental effects and /or agricultural yield are possible under certain conditions [13,31,63].

In this review, we provide an assessment of the state of the art of biochar systems for soil amendment, taking a life-cycle perspective by studying the relevant environmental aspects of its production and usage from feedstock provision, pyrolysis and long-term application to soils, and potential substitution effects. We discuss the variety of effects that biochar can have on the climate system (e.g., carbon sequestration and changes in surface albedo and in soil GHG emissions), its potential for climate change mitigation, the connections with food security, and other environmental concerns such as toxicity and ecosystems quality. We identify three main aspects that control the environmental performance of biochar systems: (1) biomass feedstock type and biochar production conditions, (2) soil properties and local climate conditions, and (3) biochar management and application practices. These three aspects are used as the main factors to explain variability of biochar effects on environmental and climate systems in the different sections of this review.

This review is structured as follows. First, we provide an overview of the various aspects of biochar deployment along its supply chain and use phase that are relevant for (1) climate mitigation and adaptation, (2) food security and soil quality, and (3) toxicity and ecosystems resilience. Global potential estimates of carbon sequestration from large-scale biochar deployment are presented and discussed in relation to the needs of CDR for specific temperature stabilization targets. We then discuss appropriate biochar feedstocks for carbon sequestration and agronomic purposes, followed by an overview of biochar production systems in terms of pyrolysis technologies and possible uses of by-products. Climate regulations mechanisms affected by biochar application to soils related to biogeochemical (e.g., global carbon, nitrogen, and water cycles) and biogeophysical (e.g., albedo and evapotranspiration) aspects are also reviewed. The different possible combinations in terms of biomass feedstocks, biochar production processes, local soil type and climate conditions, and agricultural management practice are discussed as key factors explaining variability in environmental outcomes of biochar systems. Interactions among those aspects and with factors outside the biochar value chain are also discussed, and life-cycle assessment (LCA) studies of biochar systems are reviewed. Before concluding, we discuss aspects relevant to consider for social and ethical implications of biochar deployment.

\section{Biochar and Climate Change Mitigation}

There are different aspects through which biochar systems interact with the climate. These include storage of carbon in soils, GHG emissions from the biochar value chain, changes in surface albedo from biochar application to agricultural soils, etc. These aspects are complex and highly case-specific. This section introduces these aspects and their interactions; we refer the reader to the next sections for more details on controlling factors and scale of effect. Figure 1 summarizes how biochar interacts with the climate system once incorporated in the field (not all mechanisms may happen in all cases, and some mechanisms can result in either cooling or warming depending on local conditions).

In terms of GHG emissions, biochar aims at mitigating climate change by capturing and storing atmospheric carbon in recalcitrant form, while the combined effect of increased soil organic carbon (SOC) stability and biomass yield after biochar application may also lead to an increase in stock of soil carbon in agroecosystems. Collection and transport of biomass residues require energy and is associated with GHG emissions. At the same time, collection of residues will avoid GHG emissions due to their decomposition at the cost of potential losses of SOC (see Section 6). Combustion of pyrolysis gas leads to emissions of $\mathrm{CO}_{2}, \mathrm{SO}_{2}, \mathrm{NO}_{x}$, and $\mathrm{N}_{2} \mathrm{O}$. When pyrolysis gas is not burned, pyrolysis exhausts will be composed of $\mathrm{CH}_{4}, \mathrm{CO}$ and non-methane volatile organic carbon (NMVOCs). Soil gas balances are also affected by biochar application $\left(\mathrm{N}_{2} \mathrm{O}, \mathrm{CH}_{4}, \mathrm{NO}_{x}\right.$, and $\left.\mathrm{NH}_{3}\right)$, and potentially increase emissions of black carbon and soil dust aerosols. Especially $\mathrm{N}_{2} \mathrm{O}$ and $\mathrm{CH}_{4}$ are powerful GHGs. Near-term climate forcers (NTCF) $\mathrm{NO}_{x}, \mathrm{NH}_{3}, \mathrm{CO}$, and NMVOCs are aerosol precursors that affect climate in different ways depending on the emitting region [64]. Black carbon is an aerosol with strong 
warming potential (average $900 \mathrm{kgCO} 2 \mathrm{eq} / \mathrm{kg}$ black carbon) [65], and potential emissions from field need to be better assessed. Black carbon and particulate matter can also be emitted during pyrolysis, particularly under conversion processes based on low-technology conditions [66].

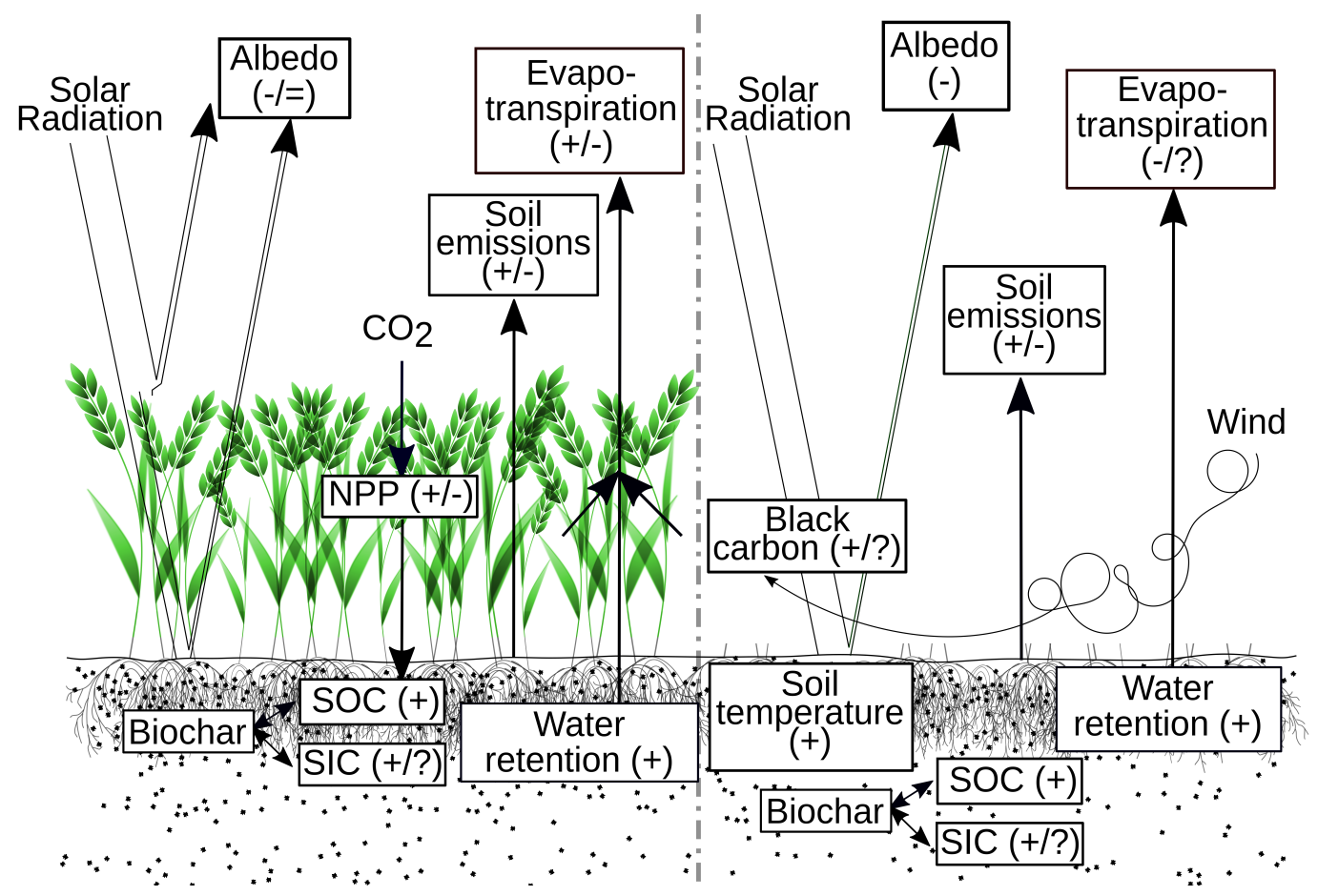

Figure 1. Biochar's effects on climate under cultivated field (left) or fallow (right) conditions. Signs in parenthesis indicate biochar's effect on the variable compared to control without biochar: $(+)$ increased, $(-)$ decreased, (=) unchanged, (?) there is limited data available for assessment. We refer the reader to Sections 2 and 8 for more detailed descriptions of the different mechanisms of how biochar in soil may affect the climate system. Soil Organic Carbon (SOC): Biochar has a positive direct effect on SOC by providing recalcitrant carbon and an indirect positive effect on SOC by stabilization of soil carbon. Some biochar carbon may be leached from soils or transported by wind (see Section 8.1) Soil Inorganic Carbon (SIC): Biochar's effect on SIC is still limited in scientific evidence, but a preliminary study shows that biochar increases SIC stock both directly and indirectly. Albedo: Biochar tends to make soils darker and, hence, to reduce surface albedo. However, the presence of a vegetation canopy or snow cover can dampen these effects. Soil emissions: Changes in soil emissions depend on the gas (i.e., $\mathrm{N}_{2} \mathrm{O}$, $\mathrm{CH}_{4}, \mathrm{NO}_{x}$, and $\mathrm{NH}_{3}$ ), biochar properties, and soil conditions (see Sections 8.1 and 8.2 for more details). Water retention: Biochar increases soil water retention and plant available water, making more water available for evapotranspiration under cultivation and evaporation under fallow. Evapotranspiration: Under cultivation, biochar has a contrasting effect on evapotranspiration depending on soil condition and climate (e.g., precipitation level and energy limitation for evapotranspiration) and can increase or decrease plant water use efficiency. Under fallow, biochar tends to reduce evaporation; however, more evidence is needed. Net Primary Productivity (NPP): Biochar has mixed effects on NPP depending on soil conditions; increased NPP fixes more carbon in vegetation, increasing residues left on field and root and increasing root exudates, which may participate in increasing SOC (see Section 8.1). Black Carbon: During application of biochar, tilling operation microparticles of black carbon can be transported by wind. Soil temperature: In the absence of crop canopy, soil temperature increases and daily soil temperature fluctuations, which can affect sensible heat flux, water evaporation, and SOC degradation rate. Under cultivation, biochar tends to decrease soil temperature fluctuations.

The Earth's surface also influences climate. Incoming energy at the soil surface is balanced by upwelling emissions of long-wave radiations and sensible, latent, and ground heat fluxes [67]. Reduced albedo due to biochar application increases short-wave absorption, making more solar energy available 
at the surface. Changes in soil albedo after biochar application is estimated to reduce its climate benefit by about $13-30 \%[68,69]$. Albedo's effect on climate depends on the amount of incoming radiation [70]. The warming effect due to reduction in soil albedo will be lower at higher latitudes, while biochar's effects on aerosol and soil moisture may affect cloud formation and the amount of radiation reaching the soil. Under cold climates and snow condition, potential transport and deposition of biochar's black carbon will decrease snow and ice albedo, and biochar-amended snow-free patches may also increase the snow melting rate on field.

Reduction in soil albedo, changes in soil water availability, and soil thermal properties due to biochar will control the proportion between sensible, latent, and ground heat fluxes, thus controlling surface temperature. Genesio and colleagues measured changes in albedo and modeled the surface energy balance of a durum wheat field in Italy [71]. They found that, overall, biochar increases all energy fluxes at a seasonal and yearly scale, while it increases soil temperatures during bare soil regime [71]. Increased soil moisture can help mitigate drought. It also increases total evapotranspiration potential, which has a cooling effect, and thus can help mitigate heat waves. Finally, soil moisture is positively correlated to the level of precipitation [72]. Biochar's effect on soil water retention and plant water availability may represent an interesting adaptation to climate change. Most of these biochar-climate interactions are discussed in detail in the following sections.

\section{Biochar, Food Security, and Soil Quality}

Biochar's positive effect on agricultural yield is often cited as an important co-benefit of its carbon sequestration. However, some negative yield responses are also observed. Biochar's effect on plants physiology and soil contaminants can also indirectly impair food security. Whether biochar increases or decreases risk of soil degradation or help reclaim degraded soil are also important aspects for food security $[73,74]$.

Several meta-analyses have investigated biochar's effect on agricultural yield [28,29,75,76]. Highly weathered soils that are acidic with low cation exchange capacity (CEC) and receive little agricultural inputs, as found in tropical regions, see a positive response to biochar application in terms of yield [29]. An average increase in yield of $25 \%$ is observed in tropical soils, while biochar has no or very little positive or even negative effects in temperate soil [29]. In tropical soils, high nutrient biochars (e.g., from manure) have a stronger positive effect on yield [29]. Increased soil moisture can increase yield in temperate regions that have less weathered soils and higher agricultural inputs $[77,78]$. Negative yield responses are mostly observed under alkaline soil conditions [29] (potentially limiting P supply to plants [79]). Application rates larger than $50 \mathrm{t}$ biochar/ha in temperate soils lead to statistically significant negative effects on yields, while tropical soil see their yield responses increase at application rates between 50-150 t biochar/ha [29] (see Table S1 in Supplementary Information (SI) based on References [29,80]).

Plant physiological responses to biochar are not all well understood yet [81]. Concerns exist regarding the role of biochar in reducing plant defense [82,83]. Biochar may lead to improved or reduced plant response toward foliar and soilborn pathogens [84]. In addition, biochar can immobilize pesticides [60], which may reduce efficiency of treatments against soilborne pathogens. Similarly, better growing conditions for crops may increase weed competition [31], while herbicides are made less efficient [85]. Biochar may affect early development of crops, as the albedo effect may warm soils and ease germination, while sorbed volatile organic carbons (VOCs) on biochar and free radical generation may impair germination [86,87].

Agricultural soil erosion is the most serious threat to agriculture sustainability and food security $[88,89]$. A decrease in agricultural yield on highly eroded fields can be as high as $65-80 \%$ [90]. Biochar can help preventing soil erosion but can also have negative effects [22,23]. Better soil hydrology and soil wet aggregate stability reduce water run-off and soil loss, but tillage can cancel biochar's positive effect [23]. Biochar may have no effect or negative effects on soil dry aggregate stability, potentially increasing wind erosion risks [22]. 
Biochar also has other potential positive effects on soils. Saline and sodic soils occupy 500 Mha of land and is expected to increase under climate change [91]. Biochar improves plant response and alleviates stress on crops grown under drought and salt stress [92,93], but its ash content may increase salinization risks and stress [93].

Removal of farm products and application of nitrogen fertilizers are responsible for acidification of croplands [74,94], which leads to lower nutrient availability, toxicity issues, nutrient leaching, and soil emissions. Biochar can act as a liming agent and can increase soil buffering capacity through carbonates, increased cation exchange capacity (CEC), and base cation provision $[95,96]$.

As a drawback, biochar may be a source of contamination by bringing polyaromatic hydrocarbons (PAHs), dioxins, VOCs , and heavy metals depending on its feedstock and production conditions $[51,53,97]$. However, biochar can immobilize heavy metals through sorption, precipitation, and $\mathrm{pH} /$ oxidoreduction reactions and was shown to consistently reduce plant heavy metals concentration [59]. Biochar may act as a source of PAHs in soils; however, observed concentrations remain below the maximum acceptable limit [51]. Biochar has the capacity to adsorb pesticides, potentially leading to accumulation in soils $[60,62]$, though they become less available and may also be degraded by biochar $[60,98]$.

\section{Biochar, Toxicity, and Ecosystems}

Emissions of reactive nitrogen from combustion and $\mathrm{N}$ fertilizer use have repercussions on human and ecosystem health via a variety of pathways [99]. These nitrogen emissions have effects on soil acidification [100], toxicity and human health [101], global nutrient biogeochemical cycle, and deposition [102] with implications for ocean and land carbon sinks [103] and land ecosystems [104]. Gas emissions during pyrolysis $[66,105,106]$ and dust and black carbon emissions from soils are also potential threats to human and ecosystem health [107].

Liu and colleagues [45] investigated global biochar deployment scenarios aiming at maximizing plant production, minimizing soil $\mathrm{N}_{2} \mathrm{O}$ emissions or soil total $\mathrm{N}$ losses, e.g., $\mathrm{N}_{2} \mathrm{O}, \mathrm{NH}_{3}$, and $\mathrm{N}$ leaching (while limiting other negative outcomes). Because each $\mathrm{N}$ species fate in soil is affected differently by biochar, they find that, depending on the scenario considered, $\mathrm{NH}_{3}$ volatilization decreases by $12 \%$ or increases by $29 \%$. Once in the atmosphere, $\mathrm{NH}_{3}$ creates particulate matter, playing a role for atmospheric haze (with cooling effect), that has serious effect on human health and alters the climate system. Part of $\mathrm{NH}_{3}$ is deposited back on terrestrial and aquatic ecosystems, where it causes acidification, eutrophication, and fertilization [99].

Biochar affects soil $\mathrm{NO}_{x}$ emissions while, during pyrolysis, part of the nitrogen in feedstock is volatilized and lead to emissions of $\mathrm{NO}_{x}$ precursors. Biochar effect on soil $\mathrm{NO}_{x}$ emissions is, however, much less studied then $\mathrm{N}_{2} \mathrm{O}$ or $\mathrm{NH}_{3}$ emissions. $\mathrm{NO}_{x}$ increases tropospheric ozone concentrations, causing particulate matter (PM). Both ozone and PM have serious effects on human health; ozone can be also deposited and can reduce productivity of ecosystem (including crops). $\mathrm{NO}_{x}$ also causes acidification, eutrophication, and fertilization once deposited on terrestrial or aquatic ecosystems [99]. Pourhashem and colleagues estimates the value of reducing soil $\mathrm{NO}_{x}$ emissions due to biochar application to be 660 million dollars per year in the US [101].

Biochar reduces nitrate $\left(\mathrm{NO}_{3}^{-}\right)$leaching but has mixed effect on leaching of ammonium $\left(\mathrm{NH}_{4}^{+}\right)$ and phosphorus [23]. Nitrogen and phosphorus leaching from agricultural fields are well known for eutrophication of freshwater and marine ecosystem [108] and also affect groundwater and drinking water quality. In their global assessment, Liu and colleagues [45] estimate that biochar has potential to reduce soil $\mathrm{N}$ leaching by $12-29 \%$ (see more information in the previous paragraph). In Blanco-Canqui's review [23], he reports changes in P leaching from decrease of $62 \%$ to increase by $152 \%$.

Exposition to black carbon PM can happen during the handling of biochar, in its application to soils, and by wind transport. Grinding of biochar to increase its specific surface area for adsorption purposes can transform $2-5 \%$ of biochar to particles under $2.5 \mu \mathrm{m}$ and $10 \mu \mathrm{m}$ [109]. Aging, abrasion, and tilling in soils and being transported can also reduce biochar to fine particles [110-112]. 
Black carbon particles are toxic to humans and ecosystems. In particular, they represent a risk for lung and heart diseases and could transport contaminants from soils to humans [107].

Dissolved organic carbon (DOC) affects aquatic ecosystems through a variety of mechanisms, such as metal toxicity, turbidity, higher temperature stratification, and lower light penetration in lakes $[113,114]$. Biochar was found to increase leaching of dissolved organic carbon $[23,115]$. Leachate of soil biochar may also be toxic to terrestrial and water ecosystems due to heavy metals and PAHs $[52,53]$. Dissolved biochar molecules may produce toxic reactive oxygen species under sunlight in water ecosystems $[116,117]$.

If carefully produced, biochar has limited potential to pollute soils and can help as a remediation tool [53]. As a remediation tool, biochar decreases bioaccumulation of heavy metals in plants, thus reducing risk toward human health $[118,119]$ (see Table S2 based on References $[51,62,97,120,121]$ ). However, its sorption capacity renders pesticides less mobile and reduces their biodegradation $[60,61]$. This has mixed benefits as it reduces the fate of pesticides in groundwater and toxicity toward non-targeted organisms, reduces pesticide efficiency toward pests, and might require higher application rates, increasing expositions to humans and ecosystems $[62,122]$.

\section{Negative Emissions and Biochar}

In terms of CDR potential, available estimates for biochar deployment largely differ in the literature and range from 0.65 to $35 \mathrm{GtCO}_{2} \mathrm{eq} /$ year depending on a wide set of assumptions [9,123-131]. For example, Lehmann and colleagues [9] provide an estimate of $2.13 \mathrm{GtCO}_{2} \mathrm{eq} / \mathrm{yr}$ assuming a replacement of burning management in shifting agriculture to biochar production, the use of forestry and crop residues, and current bioenergy needs met by pyrolysis. They also estimate biochar potential between 20-34 $\mathrm{GtCO}_{2} \mathrm{eq} / \mathrm{yr}$ assuming that all 2100 bioenergy needs are fulfilled by pyrolysis with a yield of $30.6 \mathrm{kgC}$ sequestered by GJ of bioenergy. Laird and colleagues [128] give a current potential of biochar of $1.5-3.3 \mathrm{GtCO}_{2} \mathrm{eq} / \mathrm{yr}$, assuming $50 \%$ and $67 \%$ of crop and aboveground forestry residues are used, respectively, while the upper bound adds $67 \%$ of belowground forest residues, thinning of disease-ridden forest, and application of pyrolysis to avoid $50 \%$ of human biomass burning emissions.

Most studies estimating negative emissions from biochar deployment constrain its production to the supply of forestry and crop residues. However, dedicated crops grown on abandoned and marginal land can provide additional feedstock for biochar production with potential co-benefits (see Section 6). Woolf and colleagues [125] assume a potential of 0.6-1.1 $\mathrm{GtCO}_{2} \mathrm{eq}$ biochar per year produced from crops grown on degraded and abandoned land. It adds $26-32 \%$ of biochar production potential on top of their estimates of $1.3-3.0 \mathrm{GtCO}_{2}$ eq biochar produced from residues. Powell and Lenton [126] include production of bioenergy crops on abandoned land in their assessment of CDR potential toward 2050. These crops are used only for BECCS in their scenarios but would represent a biochar production of about 3-6.2 $\mathrm{GtCO}_{2} \mathrm{eq} / \mathrm{yr}$ in 2050 (they assume $10 \mathrm{t}$ dry matter/hectare on 0.33-0.69 Gha made available in 2050). Adding both potentials (from residues and dedicated crops), a total of 7.8-10.3 $\mathrm{GtCO}_{2} \mathrm{eq} / \mathrm{yr}$ is reached.

Schmidt and colleagues [17] investigate the potential to sequester bio-oil in geological deposits in addition to biochar. This strategy increases the carbon sequestration efficiency by a factor $\sim 1.7$ (from $30-42 \%$ to $53-74 \%$ ) [17], which corresponds to an increase in negative emission from $0.65-35 \mathrm{GtCO}_{2} \mathrm{eq} / \mathrm{yr}$ (biochar only) to 1.1-60 $\mathrm{GtCO}_{2} \mathrm{eq} / \mathrm{yr}$ (biochar and bio-oil).

Figure 2 shows the range of potential estimates of negative emissions from biochar within the context of the scale and deployment rate of negative emissions that are required to stay within a given temperature warming level since preindustrial times [132]. The size of required negative emissions is related to the time of peak emissions and the size of the overshoot, with longer delays to curb emissions requiring larger deployment of NETs in the second half of the century $[16,133]$. Needs for CDR remain below $5 \mathrm{GtCO}_{2} \mathrm{eq} / \mathrm{yr}$ before 2030 but rapidly increase to more than $20 \mathrm{GtCO}_{2} \mathrm{eq} / \mathrm{yr}$ in the case of meeting the Paris agreement with high chance to overshoot the $1.5^{\circ} \mathrm{C} \operatorname{target}\left({ }^{\prime} 1.5^{\circ} \mathrm{C}\right.$ high overshoot'). 
With estimated negative emissions between $0.1-3.3 \mathrm{GtCO}_{2} \mathrm{eq} / \mathrm{yr}$, biochar can play a significant role in providing CDR for all temperature pathways until 2030, which is the year considered for current potentials (Figure 2). From 2050 onward, biochar produced from residues has a negative emission potential of $1.1-4.9 \mathrm{GtCO}_{2} \mathrm{eq} / \mathrm{yr}$, which is in the bottom $10 \%$ of the required range for the ${ }^{\prime} 1.5{ }^{\circ} \mathrm{C}$ low overshoot' pathways. Including biochar production from dedicated crops at 7.8-10 $\mathrm{GtCO}_{2} \mathrm{eq} / \mathrm{yr}$ [126], biochar is respectively in the $35 \%$ and $15 \%$ ranges of CDR deployment for pathways meeting the 1.5 ${ }^{\circ} \mathrm{C}$ target with low or high overshoot toward 2100 and in the $50-35 \%$ range of the required deployment for a lower $2{ }^{\circ} \mathrm{C}$ pathway (see Table S3 in SI). If bio-oil is also sequestered under the most optimistic biochar deployment scenario ( $\left.17.5 \mathrm{GtCO}_{2} \mathrm{eq} / \mathrm{yr}\right)$, biochar sequestration provides substantial CDR for pathways consistent with the $1.5^{\circ} \mathrm{C}$ target (see Table S3 in SI).
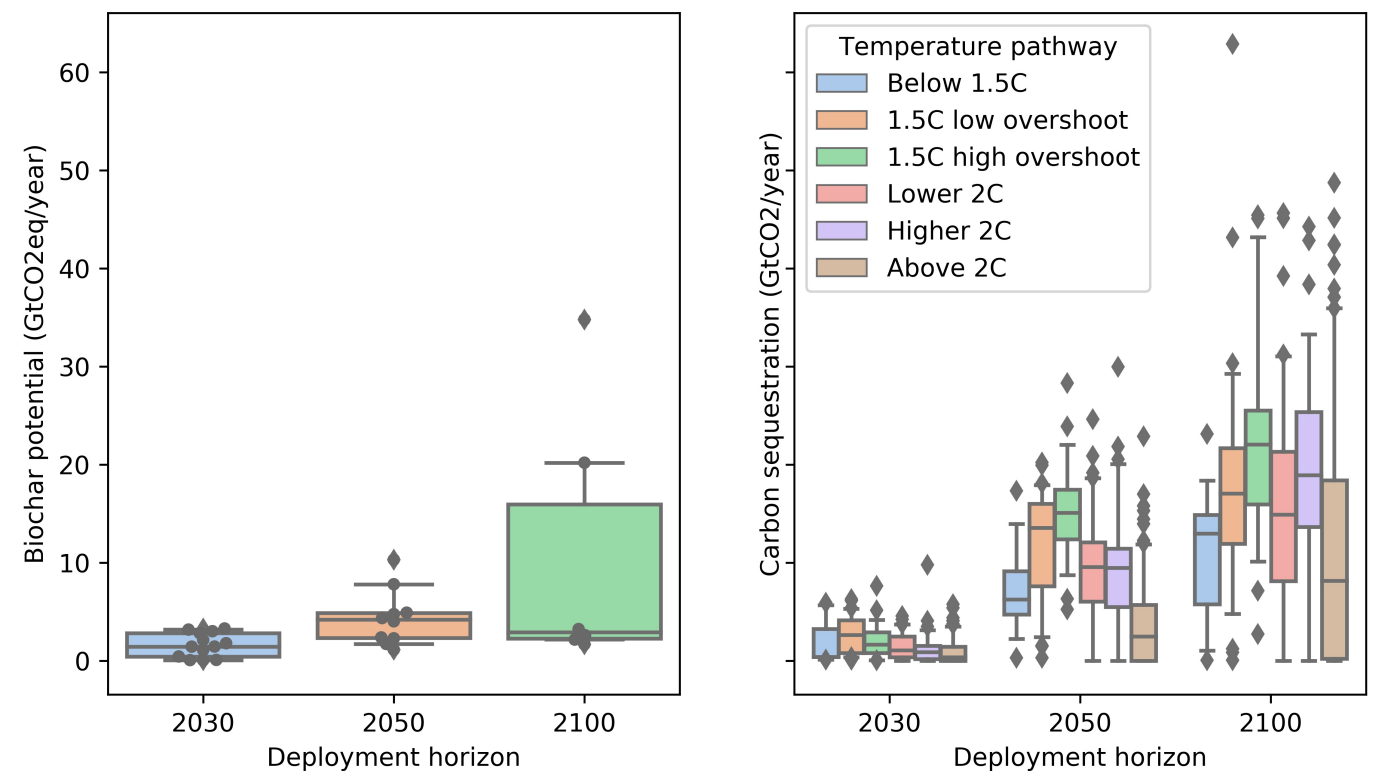

Figure 2. Biochar's potential for carbon dioxide removal (CDR) at different time horizons (left) and negative emission requirements for different time horizons and temperature pathways (right): Estimates of biochar potential come from 10 studies [9,123-131]. Studies estimating the current biochar's potential are under the 2030 horizon. CDR requirement numbers are taken from the Integrated Assessment Modeling Consortium $1.5^{\circ} \mathrm{C}$ scenario explorer [132]. CDR requirements are calculated as the sum of the variables "Carbon Sequestration I CCS", "Carbon Sequestration I Land Use", "Carbon Sequestration I Direct Air Capture", and "Carbon Sequestration I Enhanced Weathering". Only 9

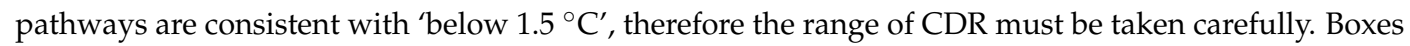
represents the 1st and 3rd quartiles, with the middle line being the median; whiskers represent the 5 th and 95th percentiles. Black diamonds represent outliers, i.e., values below the 5 th percentile or above the 95th percentile, while black circles represent individual biochar production potential estimates.

The use of dedicated energy crops is essential to achieving large negative emissions from biochar deployment. In order to avoid competition for land and detrimental effects for food security and natural systems, changes in existing land management and higher efficiency of land use is needed to free areas for the sustainable growth of dedicated biomass crops for biochar production. This can be achieved via parallel developments of multiple response options aiming at reduction of food waste, dietary changes (lower meat consumption and declines in pasture lands), and increase in yields [134].

The global land sink for biochar application is estimated between 2 Gha and up to the total agricultural land area of 4.5 Gha $[9,125,131,135]$. Estimates for carbon sink can be as high as 2200 $\mathrm{GtCO}_{2}$ eq; however, these estimates either assume that all agricultural areas are receive biochar [135] or at high application rates ( $\geq 170 \mathrm{t}$ biochar/ha) [131]. These estimates seem unrealistic given that it would include all grassland and that significant negative yield responses are observed in temperate 
soils at application rates over $50 \mathrm{t}$ biochar/ha (see Section 3). Woolf and colleagues [125] consider that about 2 Gha of global agricultural land ( $16 \%$ of global land area) is available to receive biochar (1.5 Gha of global cropland and $20 \%$ of 2.5 Gha of global pasture). The biochar application rate is commonly between 20-50 $\mathrm{t}$ biochar per hectare and could be as high as $150 \mathrm{t}$ biochar per hectare, in certain regions [29] (see Section 3). Total biochar sink potential could be somewhere between 180-410 $\mathrm{GtCO}_{2}$ eq considering a global average application rate between 30-70 $\mathrm{t}$ biochar per hectare (at $80 \%$ carbon in biochar [17]). It represents only $5-15 \%$ of the range of global cumulative CDR needed (see Table S4 in SI based on Reference [132]).

In addition to the biochar contribution to CDR deployment, biochar can provide further co-benefits, such as yield improvements, bioenergy, and reduction in soil GHG emissions, and can represent a NET that can co-deliver across multiple societal challenges. In their biochar assessment, Woolf and colleagues [125] estimated that carbon sequestration in biochar accounts for about $50 \%$ of its climate mitigation potential, while 30\% comes from replacement of fossil-fuel energy by pyrolysis energy and $20 \%$ from avoided soil emissions of $\mathrm{N}_{2} \mathrm{O}$ and $\mathrm{CH}_{4}$. Their estimate of total carbon abatement from biochar is between 3.7-6.6 $\mathrm{GtCO}_{2}$ eq per year (see also Section 9).

In general, potential production and carbon storage of biochar is much lower than BECCS but biochar is more technologically mature, can be deployed at lower costs, and has multiple co-benefits $[5,136]$. Biochar thus represents a practicable solution to ramp up negative emissions in the short-medium term, before large-scale implementation of BECCS will become feasible.

\section{Feedstock Types and Supply}

Biochar can be produced from a variety of feedstocks, which influence its composition and effects on soils. Carbon-rich feedstocks such as lignocellulosic biomass allow for higher carbon content in biochar. In particular, woody materials contain less extractives (e.g., sugars and metabolites) and more lignin than leafy, herbaceous materials and, therefore, are richer in carbon [137-140]. Higher levels of lignin are also associated with higher levels of aromatization and larger aromatic clusters that are key indicators of biochar recalcitrance and stability in soils [141-143].

On the other hand, organic waste products such as manure, sewage sludge, or food wastes contain less carbon [144] but are richer in nutrients (N, P, and K) [144] and, therefore, are more attractive for agronomic purposes than lignocellulosic biomass. However, biochar made from organic waste products are more alkaline than lignocellulosic biomass $[145,146]$ and have higher salt content, which may also lead to negative effects for plant growth and soil biota due to increases in soil $\mathrm{pH}$ and salinity [147-149]. There are also higher risks that biochar can contain toxic compounds (e.g., polychlorinated dibenzo-p-dioxins and -furans-PCDD/Fs) formed during pyrolysis [120,150] with potential toxic effects on soils. The higher heavy metal concentration in sewage sludge and digestate can represent an additional risk of soil contamination $[53,97,150]$.

There are different patterns for the supply of biochar feedstock that is associated with positive and negative side effects. Forest and crop residues are usually the by-products of other production systems and are usually associated with little additional upstream negative environmental impacts. However, their availability is limited and there can be competition for their use, as they can also serve other purposes (e.g., energy production or animal feed). Trade-offs between different uses will lead to trade-offs or co-benefits between different environmental concerns. Using manures (or digestate) could allow to recycle nutrients to agricultural land (see Section 8.2), while avoiding emissions (e.g., $\mathrm{CO}_{2}, \mathrm{~N}_{2} \mathrm{O}, \mathrm{CH}_{4}, \mathrm{NO}_{x}$, and $\mathrm{NH}_{3}$ ) [151,152] associated with their handling (i.e., composting or land spreading) that have negative effects, for example, on climate, acidification, and human health. Collection of forestry or crop residues can have consequences for soil carbon $[153,154]$, at least for the short-term; for nutrient cycling; and for maintaining soil integrity (e.g., soil structure, soil biodiversity, and erosion prevention) [154,155], but at the same time, it prevents emissions from organic matter decomposition (e.g., $\mathrm{CO}_{2}$ and $\mathrm{N}_{2} \mathrm{O}$ ) [156]. The use of dedicated crops can achieve the largest supply potential for biochar production, but it can lead to competition for land, food security, biodiversity, and 
environmental degradation from fertilizer and pesticide use [6,7]. On the other hand, bioenergy crops grown on marginal land or abandoned cropland are often win-win solutions in terms of renewable energy supply, increases in soil organic carbon, and a variety of ecosystem services relative to annual crops [157-159].

\section{Biochar Production}

Pyrolysis consists of a large family of processes and reactor technologies. Heating rates and temperature characterize different types of pyrolysis, which yield different mixtures of the three products [160,161] (Table 1). Slow pyrolysis (i.e., low heating rate and moderate temperature) favors biochar formation, fast pyrolysis, bio-oil, gasification, and syngas. With increasing pyrolysis temperature, biochar yield decreases but carbon content and aromatic condensation of biochar increases, suggesting a trade-off between higher recalcitrance at the expense of biochar yields [143,145,161,162].

Table 1. Summary of typical operating conditions and product yield of the main pyrolysis processes [163-166].

\begin{tabular}{cccc}
\hline & Slow Pyrolysis & Fast Pyrolysis & Gasification \\
\hline Pyrolysis temperature $\left({ }^{\circ} \mathrm{C}\right)$ & $250-750$ & $550-1000$ & $\geq 500$ \\
Heating rate $\left({ }^{\circ} \mathrm{C} / \mathrm{s}\right)$ & $0.1-1$ & $10-200$ & $5-100$ \\
Feedstock particle size $(\mathrm{mm})$ & $5-50$ & $\leq 1$ & $0.2-10$ \\
Solid residence time & $450-550 \mathrm{~s}$ up to days & $0.5-10 \mathrm{~s}$ & $\geq 1 \mathrm{~h}$ \\
Vapor residence time & $5-30$ min & $\sim 1 \mathrm{~s}$ & $10-20 \mathrm{~s}$ \\
Biochar yield $(\%)$ & $45-20$ & $5-30$ & $\sim 5$ \\
Bio-oil yield $(\%)$ & $40-50$ & $50-75$ & $\sim 10$ \\
Syngas yield $(\%)$ & $10-25$ & $5-35$ & $\sim 85$ \\
\hline
\end{tabular}

Fast pyrolysis and gasification are more suited for energy recovery purposes, as they favor production of bio-oil or syngas, respectively [160,161]. Biochar produced under these conditions are less suited for climate change mitigation and application to soils due to lower yield and carbon content (low carbon storage efficiency), energy costs during pretreatment of feedstock and pyrolysis, and higher risks of contamination (e.g., PAHs, dioxins, and VOCs) [17,51,53,120,143,144,167].

Both biochar's feedstock and pyrolysis conditions influence the biochar's properties. Table S5 (based on References [96,144,145,168-181]) in the supplementary information shows a summary of key biochar properties together with indications of how feedstock selection and pyrolysis conditions influence them.

Multiple uses are possible for the biochar coproducts. Bio-oil can be used directly for energy and heat purposes, but its high oxygen content, high water content (typically between 20-30\%), and low $\mathrm{pH}$ represent a challenge for its direct use [139,165]. Refining and upgrading of bio-oil is required for its use as bio-fuel but at the expense of increased costs and decreased energy efficiency [139,165]. Bio-oil is investigated as an additional option to provide carbon sequestration. Long-term storage of carbon can be achieved by pumping bio-oil directly in geological formation [17]. Biorefining of bio-oil has also potential to replace some petroleum-based feedstocks in the chemical industry [182] for the production of asphalt paving substitution, slow release fertilizer, pesticides and wood preservatives, resins and adhesives, or carbon fiber. Integrated in products, bio-oil would represent temporary carbon sequestration, similar to wood in wood products [183].

Syngas can be used in turbines to produce electricity or to provide heat to sustain the pyrolysis and/or to dry the feedstock [184]. Under certain conditions, syngas production during slow pyrolysis contains enough energy required to sustain the pyrolysis [185].

Biochar production is a key step for its overall environmental sustainability profile. Thermal decomposition of biomass leads to formation of a wide variety of compounds that can represent an environmental risk if not properly handled. Bio-oil and tars contain compounds toxic to humans 
and ecosystems $[106,186]$. Biochar can contain PAHs and VOCs sorbed on its surface that can be toxic to soil biota and induce physiological responses in plants, such as affecting seed germination and nutrient uptake $[51,86,120]$. Syngas, on the other hand, consists mostly of a mixture of $\mathrm{CO}_{2}, \mathrm{CO}$, $\mathrm{CH}_{4}$, and $\mathrm{H}_{2}$ gases that have negative effects on climate or are toxic: $5-28 \%$ of biomass nitrogen is transferred to the bio-oil or gas phase during pyrolysis and emitted as $\mathrm{N}_{2} \mathrm{O}$ or $\mathrm{NO}_{x}$ [46]. Chlorine and sulfur can also be vaporized, leading to emissions of $\mathrm{CH}_{3} \mathrm{Cl}$, dioxins, and $\mathrm{H}_{2} \mathrm{~S}[150,187]$. Appropriate handling of the biochar coproducts is required to mitigate these risks. In particular, even without energy or heat recovery, combustion of pyrolysis gases (both vaporized bio-oil and syngas) is preferred to lower emissions of toxic compounds [66,105].

\section{Biochar in Soils: Biogeochemical and Biophysical Effects}

Biochar affects soil physical (e.g., density, aeration, and colour), chemical (e.g., pH and oxidoreduction potential), and biological properties (e.g., macrobial biomass and community composition). These changes in soil conditions have consequences on global biogeochemical cycles (e.g., carbon, nutrient, and water cycles) and biophysical balance (e.g., soil albedo and temperature; surface energy balance) of the Earth's system. In this section, we describe how biochar interacts with the Earth's system and provide main controls of the interaction regarding biochar properties, soil type, and management.

\subsection{Soil Carbon}

The main process through which biochar interacts with the carbon cycle is by sequestering atmospheric $\mathrm{CO}_{2}$ during vegetation growth and by storing a large fraction of this carbon in soils in recalcitrant form.

Biochar is made of a highly recalcitrant carbon structure toward biotic and abiotic reactions $[20,188]$. Estimation of residence time under field conditions range from 6 to 5448 years [189]. Biochar decomposition follows a two-pool behavior, with a labile fraction that is quickly degraded and a recalcitrant fraction respectively estimated at 3 and $97 \%$ in a meta-analysis [20]. Based on the meta-analysis [18], average decomposition rates of biochar quickly drop from $0.6433 \%$ /day to $0.0024 \%$ /day after one year, due to depletion of the labile pool and then slow degradation of the recalcitrant pool [18]. Table 2 presents key production parameters increasing biochar recalcitrance: pyrolysis time $(>3 \mathrm{~h})$ and temperature $\left(>400{ }^{\circ} \mathrm{C}\right)$. Biochar decomposition in soils is lower under acidic conditions (steep decrease between $\mathrm{pH} 6$ and 5$)$, dry climates ( $<40 \%$ moisture), and lower temperature.

Table 2. Key parameters controlling biochar stability in soils.

\begin{tabular}{|c|c|c|c|}
\hline Cont & ling Factors & Observations & Ref \\
\hline \multirow{3}{*}{ Biochar } & Pyrolysis time & $\begin{array}{l}\text { Pyrolysis reaction time longer than } 3 \mathrm{~h} \text { markedly decreases decomposition rate of } \\
\text { biochar. }\end{array}$ & [18] \\
\hline & $\begin{array}{l}\text { Pyrolysis } \\
\text { temperature }\end{array}$ & Pyrolysis temperature over $400^{\circ} \mathrm{C}$ produces more stable biochar. & {$[18,20]$} \\
\hline & Carbon content & $\begin{array}{l}\text { Higher biochar carbon content is linked to lower } H / C_{\text {org }} \text { ratio and higher degree } \\
\text { of aromatic condensation of biochar, which are important control of its stability. } \\
\text { Carbon content over } 70 \% \text { have significantly lower decomposition rates. }\end{array}$ & {$[18,142,171]$} \\
\hline \multirow{5}{*}{ Soil } & $\mathrm{pH}$ & $\begin{array}{l}\text { Soils with low } \mathrm{pH} \text { show lower degradation rates of biochar. Decomposition rate is } \\
\text { increased by } 272 \% \text { from } \mathrm{pH} 5 \text { to } \mathrm{pH} 6 \text {. }\end{array}$ & [18] \\
\hline & Moisture & $\begin{array}{l}\text { Increasing soil moisture increases biochar decomposition rates by } 200 \% \text { from } 40 \% \\
\text { to } 70 \% \text { water content. }\end{array}$ & [18] \\
\hline & Temperature & A $20^{\circ} \mathrm{C}$ increase in temperature leads to a $53 \%$ increase in decomposition rate. & [18] \\
\hline & $\mathrm{C} / \mathrm{N}$ ratio & $\begin{array}{l}\text { Biochar decomposition rate decreases with increasing soil } C / N \text { ratio but increases } \\
\text { with soil organic carbon content. Addition of nutrient has no effect on biochar } \\
\text { decomposition rate. It seems to indicate that biochar decomposition is more } \\
\text { controlled by readily available } C \text { for energy than by nutrient limitations. }\end{array}$ & {$[20,190,191]$} \\
\hline & Mineralogy & $\begin{array}{l}\text { Higher clay content in soils lowers biochar decomposition rates. Recalcitrance of } \\
\text { biochar is also increased by the presence of certain soil minerals that slow down } \\
\text { its oxidation or by stabilizing dissolvable and undissolvable biochar. However, } \\
\text { the effect of mineralogy on biochar stability is still not much investigated. }\end{array}$ & {$[20,190,191]$} \\
\hline
\end{tabular}

$H / C_{\text {org }}$ : Hydrogen to organic carbon in biochar (excluding carbonates in biochar's ash); $\mathrm{C} / \mathrm{N}$ : carbon to nitrogen ratio. 
Biochar carbon can also be lost to $\mathrm{CO}_{2}$ outside the field. Fresh and aged biochar can release DOC [21,192] and be leached out and transported to freshwater systems [115]. Biochar's DOC contains aliphatic, carboxyl carbons and small condensed aromatic molecules [116,192]. Small and aliphatic DOCs are labile and can be oxidized in water systems [117]. Condensed aromatic DOCs are considered more recalcitrant but are also preferentially photooxidized $[117,193]$. About $8-13 \%$ of this condensed-aromatic DOC may undergo complete photooxidation and may return as $\mathrm{CO}_{2}$, while $68-91 \%$ is partially photooxidated, potentially increasing its biolability [117]. Fate of the leached DOC from biochar needs to be better assessed and quantified, as most existing studies rely on DOC from natural charcoal produced from wildfires (differing in properties [194]).

Besides being recalcitrant, biochar has also the potential to stabilize native soil organic carbon (i.e., negative priming effect on SOC), mostly due to SOC adsorption on its surface [195]. Biochar application can stimulate microbial activity after application, leading to a temporary positive priming effect but becoming negative after 2 years [19,20]. Based on a meta-analysis [19,20], time after application is the major control on biochar's priming effect. Main controls leading to negative priming include biochar production conditions: feedstock (mostly negative priming for woody and crop feedstock, mostly positive for manures and sludges), carbon content $(>50 \%)$, and temperature $(>500$ $\left.{ }^{\circ} \mathrm{C}\right)$. Soils poor in nutrient $(\mathrm{C} / \mathrm{N}$ ratio $>11-12)$, with low carbon content $(\mathrm{SOC}<1 \%)$, and acidic $(\mathrm{pH}<$ 6) are more likely to lead to a positive priming (see Table S6 in SI based on References $[19,20,196-198]$ ).

In addition to favoring stabilization of native SOC, biochar is also reported to increase soil microbial biomass [43,199], to improve root traits and biomass [200], to stabilize recent carbon inputs [198,201], and to increase sequestration of non-charred soil carbon [196,202,203], suggesting a positive carbon sequestration feedback of biochar addition to soils. For example, on cropland with old charcoal deposits from former charcoal-kiln sites (>120 years), concentration of non-charcoal C in soils is 1 to 1.4 times higher and contains 1.6-1.7 times more crop-derived carbon in the black spots than in adjacent soils without biochar $[198,204]$.

The effects of biochar on soil inorganic carbon (SIC) are little explored. Dong and colleagues [205] found that biochar increases total inorganic carbon by $20-62 \%$ in the $0-20 \mathrm{~cm}$ soil layer and by $13-31 \%$ in the 20-40 cm soil layer [205].

Soils can be a source of methane under anoxic conditions (e.g., paddy rice) or a sink of methane, where it is oxidated in upland soils [206]. Soil methane uptake represents about the size of anthropogenic emissions from rice cultivation or from biomass and biofuel. Biochar has a mixed effect on soil methane emission and uptake (see Table S7 in SI) [33,35,36,41]. Biochar can reduce methane production rates from source soils and its uptake in sink soils [35]. Cong and colleagues [36] find that only biochar addition to coarse, upland soil with moderate $(10-20 \mathrm{~g} / \mathrm{kg}$ soil) amounts of SOC leads to significant increase in the methane sink capacity, while coarse paddy rice soil with low carbon may see their methane release markedly increased (though not statically significant). Overall, Ji and colleagues [35] estimated that emission reductions from paddy rice will be offset by reductions in methane uptake in soils.

During production and handling and after field application, weathering and tilling can reduce biochar to very fine particles [110-112]. Tunnel experiments suggest that biochar particles can also be transported by wind after soil incorporation [109,111,112,207]. Three out of eight soils saw its dry aggregate stability reduced by biochar [22], increasing susceptibility to wind erosion, soil dust emissions, and potentially transport of black carbon particles. High content of monovalent cation in biochar $\left(\mathrm{Na}^{+}\right.$and $\left.\mathrm{K}^{+}\right)$may increase dust emission, while coarse and dry soil seem more responsive to biochar addition [112]. Regarding management, wet application of biochar and deep incorporation into soil can mitigate black carbon emission from soils [107]. Li and colleagues found that biochar increased PM10 black carbon emission by $4-10$ times [112]. More studies, in particular, under field conditions, are needed to evaluate the potential of wind transportation of biochar particles from field and derive realistic emission factors. 


\section{2. $N$ and $P$ Cycles}

Biochar affects nutrients cycling in soils via sorption and retention, increasing or decreasing their bioavailability by reducing or increasing emissions and leaching. Pyrolysis can volatilize some of the biomass's nitrogen, but about $75 \%$ remains in biochar in fixed forms, with relatively low availability [150]. Biomass's phosphorus remains mostly in the biochar, but its soil availability decreases with increasing pyrolysis temperature. Biochar has been suggested as a potential slow release P fertilizer $[50,150]$.

On a larger scale, biochar will influence cycling of nutrients at the ecosystem level by changing leaching and deposition of nutrients and by modifying the cycling of nutrients in residues. Collection of residues will remove nutrients that would otherwise be cycled within the ecosystem (e.g., forest) or field. Depending on whether nutrient availability and losses in the field are increased, biochar application will affect how much fertilizer need may be reduced or increased, while changes in nutrient losses from the soil will affect global nutrient cycles.

Biochar influences soil cycling of nitrogen via its surface chemistry $[176,208]$, effect on soil $\mathrm{pH}$, and response of microbial communities $[37,46]$. Biochar application tend to decrease $\mathrm{NO}_{3}^{-}$and $\mathrm{NH}_{4}^{+}$ concentrations in soils by respectively 11 and $12 \%$ [48,209]. Co-application of fertilizer, particularly organic, or co-composted biochars can alleviate the risk of $N$ supply shortage to plants $[48,209,210]$. From a meta-analysis, biochar beneficially increases $\mathrm{N}_{2}$ fixation in soil by $63 \%$ and decreases $\mathrm{N}$ leaching by $26 \%$ [46] (see Table S8 in the SI based on References [37,48,144,209]).

Crop yield enhancement effect of biochar is linked to increased $\mathrm{N}$ fertilizer efficiency and plant $\mathrm{N}$ uptake [32,211]. In their meta-analysis on plant $\mathrm{N}$ uptake, Liu and colleagues [46] found that biochar significantly increase the $\mathrm{N}$ uptake when produced at high temperature $\left(>500{ }^{\circ} \mathrm{C}\right)$ from manures, in soils with low $\mathrm{pH}(<5)$, and in $\mathrm{CEC}(<5 \mathrm{cmol} / \mathrm{kg})$ and that high application rate $(>80 \mathrm{t}$ biochar $/ \mathrm{ha})$ of biochar could significantly decrease $\mathrm{N}$ uptake in plants. Overall, they estimated an increase in $\mathrm{N}$ uptake of $12 \%$.

Increasing $\mathrm{N}$ fertilizer efficiency due to biochar allows to lower the application rate, indirectly reducing soil $\mathrm{N}$ emissions and leaching. Biochar has also a direct effect as it reduces soil emissions of $\mathrm{N}_{2} \mathrm{O}$ by $32-38 \%$ on average after biochar application to soils $[37,46]$; however, its effect may only be transient, lasting up to one year after application [37]. At the field scale, biochar's effect on $\mathrm{N}_{2} \mathrm{O}$ emissions ranges from reduction by $17 \%$ or increase by $1 \%$ [38]. Biochar decreases $47-67 \%$ soil $\mathrm{NO}_{x}$ emissions [212], though it has been less studied than $\mathrm{N}_{2} \mathrm{O}$ emission reduction. Effect of biochar on $\mathrm{NH}_{3}$ volatilization varies greatly, with a meta-analysis suggesting overall increase of $19 \%$ [46] and another one suggesting no net effect overall [47].

Soil $\mathrm{N}_{2} \mathrm{O}$ emissions mitigation from biochar amendment are higher with lower biochar's $H / C_{\text {org }}$ at higher biochar application rate and in finer textured soils. Mitigation of $\mathrm{N}_{2} \mathrm{O}$ emissions increases also with an increased application rate of biochar and under urea and nitrate fertilization (Table 3) $[37,39,40,46]$. The link between soil $\mathrm{N}_{2} \mathrm{O}$ emission mitigation and biochar's $H / C_{\text {org }}$ ratio is made in only one meta-analysis [39], though others mention that higher temperature (generally linked to lower $H / C_{\text {org }}$ ratios) and higher carbon content biochars lead to higher mitigation potential $[37,46]$. However, two meta-analyses find that mitigation of $\mathrm{N}_{2} \mathrm{O}$ emissions by biochar may only be transient [37,38]. Verhoeven and colleagues [38] conclude that no clear factors under field conditions (e.g., biochar properties, soil conditions, or management) control $\mathrm{N}_{2} \mathrm{O}$ mitigation and suggest that some previous observations may be an artifact of compiling nonindependent experiments. Lower biochar application rates, generally lower moisture content, a lack of homogeneous biochar incorporation, and overall less controlled conditions are reasons why less reductions are observed under field conditions compared to incubation studies [38,39]. Some conclusions among meta-analysis are contradicting, for example, the effect of soil pH (References [37,40] vs. References [46]) or of soil organic matter (Reference [37] vs. Reference [46]).

Reduction in soil $\mathrm{NO}_{x}$ emissions is more pronounced in acidic soils and with straw biochar compared to manure biochar and under all type of inorganic fertilizer application [13,212-214]. Overall, 
a reduction in soil $\mathrm{NO}_{x}$ emissions was observed in most of the experiments available in the literature but not in Reference [215]. It is worth noting that most of the experiments of biochar effects on soil $\mathrm{NO}_{x}$ emissions have been performed on vegetable cropping systems in China and requires more experimentations in other cropping systems and regions.

Table 3. Main controlling factors of the effect of biochar on soil nitrous oxide $\left(\mathrm{N}_{2} \mathrm{O}\right)$ emissions.

\begin{tabular}{|c|c|c|c|}
\hline Control & ing Factors & Observations & Ref \\
\hline \multirow{3}{*}{ Biochar } & Feedstock & $\begin{array}{l}\text { Lignocellulosic feedstocks (wood and crops) lead to significant reductions in soil } \\
\mathrm{N}_{2} \mathrm{O} \text { emissions. Manures and other organic waste biochars vary in response. }\end{array}$ & {$[37,40,46]$} \\
\hline & $H / C_{\text {org }}$ ratio & $\begin{array}{l}\text { Reduction in biochar } H / C_{\text {org }} \text { ratio increases mitigation of soil } \mathrm{N}_{2} \mathrm{O} \text { emissions. } \\
\text { This is consistent with higher mitigation from lignocellulosic feedstock and } \\
\text { higher production temperature having higher mitigation potential. }\end{array}$ & {$[37,39,46]$} \\
\hline & Aging & $\begin{array}{l}\text { Mitigation of soil } \mathrm{N}_{2} \mathrm{O} \text { emission by biochar is only transient, significantly } \\
\text { decreasing after a year. }\end{array}$ & {$[37,38]$} \\
\hline \multirow{3}{*}{ Soil } & $\mathrm{pH}$ & $\begin{array}{l}\text { Reference [46] found that mitigation of soil } \mathrm{N}_{2} \mathrm{O} \text { emissions by biochar is more } \\
\text { pronounced under acidic and alkaline soil conditions, with the lowest mitigation } \\
\text { potential under neutral soil } \mathrm{pH} \text {. On the other hand, Reference [37] found that } \\
\mathrm{N}_{2} \mathrm{O} \text { emission mitigation was lowest at soil } \mathrm{pH} \text { of } 6.5-7.0 \text {; Reference [40] found } \\
\text { that there is little difference in soil } \mathrm{N}_{2} \mathrm{O} \text { mitigation across soil } \mathrm{pH} \text { range but, for } \\
\text { acidic soils }(\mathrm{pH}<5) \text {, shows lowest potential and is nonsignificant. }\end{array}$ & {$[37,40,46]$} \\
\hline & Texture & $\begin{array}{l}\text { Mitigation of soil } \mathrm{N}_{2} \mathrm{O} \text { emissions by biochar increases from sandy texture } \\
\text { toward finer textures, with maximum reduction in loams. However, clayey soils } \\
\text { show the lowest mitigation potential. } \\
\text { Soil texture responds differently under different soil moisture conditions. }\end{array}$ & {$[37,40,46]$} \\
\hline & Moisture & $\begin{array}{l}\text { Under high moisture, coarse soils show large variation in response to biochar } \\
\text { with a mean negative mitigation potential of soil } \mathrm{N}_{2} \mathrm{O} \text { emissions, while other } \\
\text { textures consistently reduce emissions. } \\
\text { Under low moisture, fine soils show large variations in response to biochar, } \\
\text { while other textures show consistently mitigation in soil } \mathrm{N}_{2} \mathrm{O} \text { emissions. After } \\
\text { fertilization and under high soil moisture, biochar reduces soil } \mathrm{N}_{2} \mathrm{O} \text { emissions } \\
\text { for about } 1 \text { month; after fertilization and under low soil moisture, biochar } \\
\text { increases } \mathrm{N}_{2} \mathrm{O} \text { emissions for } 3-4 \text { days. }\end{array}$ & {$[37,46]$} \\
\hline \multirow[b]{2}{*}{ Management } & Application rate & $\begin{array}{l}\text { Increasing biochar application rate reduces } \mathrm{N}_{2} \mathrm{O} \text { emissions, with the maximum } \\
\text { potential at about } 90 \mathrm{t} \text { biochar/ha and above. Significant reductions are only } \\
\text { observed at application rates above } 10 \mathrm{t} \text { biochar/ha }(\sim 1 \% \text { application rate). }\end{array}$ & {$[37,40,46]$} \\
\hline & Fertilizer & $\begin{array}{l}\text { Biochar has more potential in decreasing soil } \mathrm{N}_{2} \mathrm{O} \text { emissions under fertilized } \\
\text { conditions, particularly in fields. Biochar does not significantly reduce soil } \mathrm{N}_{2} \mathrm{O} \\
\text { emissions from organic and ammonium nitrate fertilizer. However, it has } \\
\text { a significant effect under urea and nitrate fertilization conditions. }\end{array}$ & {$[33,37,40]$} \\
\hline
\end{tabular}

$\mathrm{NH}_{3}$ volatilization increases with increase in biochar's alkalinity, in acidic soils and with low cation exchange capacity (CEC), and under large addition of biochar. Aging of biochar will mitigate increase in $\mathrm{NH}_{3}$ emissions due to transient liming effect and increased biochar's CEC under aging (see Table S9 in SI based on References [46,47]).

Biochar increases plant available $\mathrm{P}$ in soils by $45 \%$ and microbial biomass $\mathrm{P}$ by $48 \%$ [48]. In a meta-analysis, it was found that biochar significantly increases phosphorus availability in soils for 5 years [216]. Biochars derived from manure and crop residues feedstock have higher content of $\mathrm{P}$ than other feedstock [49]. Biochar P is less mobile than agricultural residues $\mathrm{P}$ and could act as a slow-release P fertilizer. Biochar can be a P-recycling route from agricultural residues [50]. In terms of controls, crop residue and manure biochars increase soil $\mathrm{P}$ availability, less biochar-P is available at higher pyrolysis temperature, and alkaline soils may see $\mathrm{P}$ availability reduced $(\mathrm{pH}>7.5)$ due to biochar's liming effect (see Table S10 in SI based on References $[48,216])$.

Leaching of nutrients ( $\mathrm{N}$ and $\mathrm{P}$ ) is affected by biochar as (1) it affect their availability in soils (see Tables S8, S10, and S11 in SI based on References [144,217]) and (2) it affects soil water regime in soils (see Table S12 in SI based on References [22-24,170,218-221]).

\subsection{Water}

Biochar improves soil water status by increasing the water holding capacity (more in coarser than finer soils) and by increasing the hydraulic conductivity in fine soil but by decreasing it in 
coarse soil [22,24]. Higher macroporosity and lower hydrophobicity of biochar increase soil water retention [170]. Interactions between biochar particles and soil aggregates are also important in modifying water holding capacity and water flow in soils by increasing or reducing soil interpore volume $[22,219,220,222]$. Better soil wet aggregate stability and soil consistency could also reduce pore clogging under wet conditions [22]. Biochar effects on soil water cycle also allow for increasing plant water availability [22,24,25]. Plant water use efficiency is also improved in certain studies but not always [25,92]. A minimum of 20-25 $\mathrm{t}$ biochar per hectare may be required to effectively increase soil available water capacity and to significantly modify soil hydraulic conductivity [22,24] (see Table S12).

\subsection{Biophysical Effects}

Biochar application will affect soil temperature via several interacting mechanisms: decreased soil albedo, increased soil moisture, reduction in soil volumetric heat capacity, conductivity, and diffusivity [22,223]. Patterns are different whether crop is present: biochar increases daily and seasonal soil temperature fluctuates in the absence of crops [224] and reduces it under cultivation [224-226]. Yan and colleagues [226] found that average soil temperature, average of the lowest and highest daily soil temperatures, and whole accumulated soil temperature is higher under biochar treatment, which may have consequences for soil carbon cycling, plant germination, and growth.

Biochar is a black material capable of absorbing light. Changes in light absorbance affect surface albedo. Genesio and colleagues [71] found that reflectance of soil biochar mixtures (30 and $60 \mathrm{t}$ biochar/ha) decreased across all frequencies, while Zhang and colleagues [227] (4.5 and $9 \mathrm{t}$ biochar/ha) found that reflectance in the short-wave domain $(350-500 \mathrm{~nm})$ was increased and decreased otherwise (500-2474 nm).

Changes in light absorbance affect surface albedo. Reduction in soil albedo due to biochar has been measured to be in range of 0.1 point [22]. At similar biochar application rate, decrease in soil albedo tend to be larger in lighter soils than darker ones [228]. However, soils with albedo of about 0.087-0.125, biochar's effect is not appreciable [228]. Soil albedo decreases with increasing biochar application rate [228], but tend to level off after a certain additional amount [71,225,228]. Crop canopy masks the effect of biochar on soil albedo [69,71] but not always completely [68,224]; the masking effect is related to the leaf area index [225]. Albedo of biochar amended soils is $32-58 \%$ lower under wet conditions compared to dry conditions [228]; biochar may also have an indirect effect on albedo as it increases soil moisture. Reduction in soil albedo can be mitigated by management choices: by tilling, which may mitigate the decrease in soil albedo after biochar application [71], though black spots on cropland with historical charcoal deposits (>120 years) are still visible [201]; by choosing crops with earlier canopy development [225] or cultivars with higher albedo [71]; or by using cover crops instead of leaving soils bare.

Biochar effects on soil water retention [22,24], soil water evaporation [229], and plant available water $[22,24,25]$ also affect surface energy balance by affecting the partitioning of the incoming energy between sensible and latent heat [67]. Fischer and colleagues [25] also estimated that biochar increases evapotranspiration by about 5\% in a coarse soil at about $150 \mathrm{t}$ biochar/ha, as more water entering soil is stored and available to plants for evapotranspiration. Koide and colleagues [230] found an increase in 0.8-2.7 days of transpiration after biochar addition. Increased evapotranspiration would have a cooling effect.

\section{Life-Cycle Assessment of Biochar Systems}

We revised 34 studies performing life-cycle assessments (LCAs) of a biochar system with land application. Table 4 shows a summary of the most common assumptions and modeling approaches chosen by these studies, and Figure 3 shows a summary of the climate change impacts of biochar systems. Positive values in Figure 3 correspond to net emissions of GHGs, while negative values represent net avoided emissions of GHGs or sequestration of carbon (e.g., positive values indicates warming, while negative values indicate cooling). When possible, climate change impacts of biochar 
systems are shown across the main life-cycle stages, i.e., supply chain and pyrolysis, avoided emissions from coproducts, carbon sequestration in soils, and effects to soil emissions [69,123,151,152,231-235]. Some studies do not provide the required disaggregation of the data accross the different life-cycle stages, and in this case, only the total score is included in Figure 3 [236-248]. Some LCA studies define their functional unit as "per tonne of crop" or "per hectare cultivated" and did not provide conversion factors to transform their results into "per tonne of feedstock" as presented in Figure 3 [249-260]. As such, results from these studies are qualitatively discussed but not included in Figure 3. Studies are distinguished by feedstock type: herbaceous (like grasses, leafy or crop biomass), wood (forest residues or dedicated short-rotation coppice), and organic waste (manure or digestate) (Table S13).

Table 4. Main assumptions and modeling approaches for biochar system in life-cycle assessment studies.

\begin{tabular}{|c|c|c|}
\hline Parameter & Typical Assumption & Ref \\
\hline \multirow{2}{*}{ Biochar stability } & $15 / 85 \%, 20 / 80 \%$, or $30 / 70 \%$ fraction of labile/recalcitrant fractions in biochar & {$[123,237,251,256]$} \\
\hline & Remaining carbon in biochar after 100 year in soils: $68 \%$ & {$[69,151,152,231]$} \\
\hline \multirow{3}{*}{ Reduced fertilizer use } & Nitrogen: $7.2-10 \%$ and up to $25-30 \%$ reduction & $\begin{array}{l}{[69,123,152,231-} \\
233]\end{array}$ \\
\hline & Phophorus: $5-7.2 \%$ reduction & $\begin{array}{l}{[69,123,152,231} \\
232,251]\end{array}$ \\
\hline & Potassium: $5-7.2 \%$ reduction & $\begin{array}{l}{[69,123,152,231} \\
\quad 232,251]\end{array}$ \\
\hline Reduced soil $\mathrm{N}_{2} \mathrm{O}$ emissions & $\begin{array}{l}15 \text { to } 50 \% \text { reduction in soil } \mathrm{N}_{2} \mathrm{O} \text { emissions; some studies model the transient } \\
\text { effect of biochar on soil } \mathrm{N}_{2} \mathrm{O} \text { emissions; reduction of } \mathrm{N}_{2} \mathrm{O} \text { emission } \\
\text { via reduced application of } \mathrm{N} \text { fertilizer }\end{array}$ & $\begin{array}{l}{[69,123,151,152,} \\
231-233,249]\end{array}$ \\
\hline $\begin{array}{l}\text { Changes in soil } \mathrm{CH}_{4} \\
\text { emissions/uptake }\end{array}$ & $\begin{array}{l}20 \% \text { reduction in soil } \mathrm{CH}_{4} \text { emissions in paddy rice field; reduced upland soil } \\
\text { methane sink by } 0-50 \%\end{array}$ & {$[151,251,252]$} \\
\hline \multirow[t]{2}{*}{ Effect on SOC } & $\begin{array}{l}\text { Changes in SOC through increase in NPP ( } 5-10 \% \text { increase) and negative } \\
\text { priming on native SOC ( } 5-10 \% \text { decrease in decomposition rate); sensitivity } \\
\text { analysis on SOC change from }-12 \text { to }+21 \%\end{array}$ & {$[152,231]$} \\
\hline & Additional sequestration of $4 \mathrm{tC} /$ ha over 30 years, $3.4 \mathrm{tC} /$ ha over 25 years & {$[151,232]$} \\
\hline Soil leaching & Reduced heavy metal leaching from soils & {$[244,245]$} \\
\hline \multirow{3}{*}{ Functional unit } & $\mathrm{CO}_{2} \mathrm{eq} / \mathrm{kg}$ feedstock & $\begin{array}{l}{[69,123,152,231-} \\
233,244,245,248 \\
256,258]\end{array}$ \\
\hline & $\mathrm{CO}_{2} \mathrm{eq} / \mathrm{kg}$ biochar & {$[237-240,254,259]$} \\
\hline & $\mathrm{CO}_{2} \mathrm{eq} / \mathrm{kg}$ food produced & {$[249-252,257]$} \\
\hline \multirow{3}{*}{ Biochar's yield effect } & $\begin{array}{l}\text { Modeled via the functional unit: increased yield lowers the yield-scaled GHG } \\
\text { emissions intensity of food production }\end{array}$ & {$[251,257]$} \\
\hline & Reduced fertilizer input for similar crop yield & {$[233,240]$} \\
\hline & $\begin{array}{l}\text { Increased NPP lead to more biomass output for biochar production or } \\
\text { increases SOC }\end{array}$ & {$[152,231,241]$} \\
\hline \multirow{3}{*}{$\begin{array}{l}\text { Pyrolysis coproduct } \\
\text { treatment }\end{array}$} & $\begin{array}{l}\text { Substitution; coproducts displace other products; associated burdens are } \\
\text { substracted: electricity, residential, or industrial heat; various waste } \\
\text { treatment options; cooking fuel }\end{array}$ & $\begin{array}{l}{[69,123,125,152} \\
231,232,236-238 \\
241,252,257-259]\end{array}$ \\
\hline & $\begin{array}{l}\text { Allocation, burden/benefits distributed across coproducts by mass, energy, } \\
\text { or economic allocation }\end{array}$ & {$[239,254]$} \\
\hline & $\begin{array}{l}\text { Not treated; they are assumed to be outside system boundaries and to } \\
\text { provide neither positive substitution effects nor burden }\end{array}$ & {$[239,240,242]$} \\
\hline
\end{tabular}




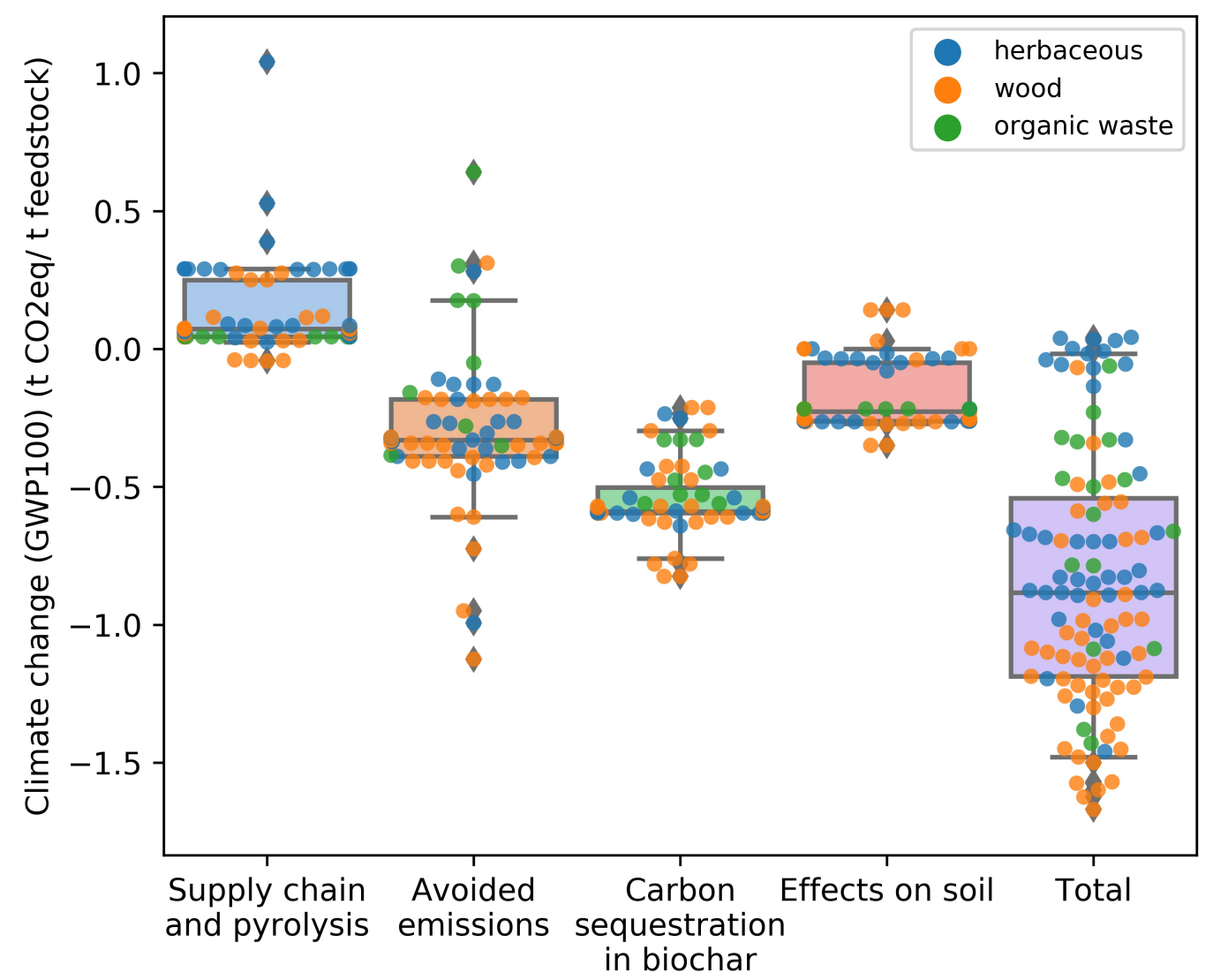

Figure 3. Survey of climate change impacts from life-cycle studies of pyrolysis systems with biochar production and application to agricultural fields: Positive values correspond to net emissions of GHGs, while negative values represent net avoided emissions of GHGs or sequestration of carbon (e.g., positive values indicates warming, while negative values indicate cooling). 'Supply chain and pyrolysis' refer to feedstock provision and pretreatment, pyrolysis, and transport; 'avoided emissions' accounts for avoided fossil carbon emissions by using bio-oil and pyrolysis gas for energy production and, in some cases, also accounts for avoided emissions due to reduced fertilizer consumption; and 'effects on soil' accounts for biochar effects on soil emissions (priming effect on $\mathrm{SOC}$ and $\mathrm{NO}_{2}$ emissions) and changes in albedo. Each dot represents one biochar-production system, dots on the same line are results that uses the same assumptions. Boxes represent the 1st and 3rd quartile, with the middle line being the median; whiskers represent the 5th and 95th percentiles. This figure is based on References [69,123,151,152,231-248].

Supply chain and pyrolysis accounts for emissions occurring during feedstock collection, preprocessing (e.g., drying and chipping), and pyrolysis (e.g., start-up and exhaust gases). We found an overall climate impact of pyrolysis systems that ranges from net emissions of 1.04 to a net avoidance of emissions of $-0.04 \mathrm{tCO}_{2} \mathrm{eq} / \mathrm{t}$ feedstock (from 5 th to 95 th percentile). Negative values are due to studies that account for avoided emissions from degradation/burning of forest residues [231,233]. Use of dedicated crops leads to higher GHG emissions due to inputs required for their production (e.g., irrigation and pesticide use) (References [231,234,241] vs. Reference [152]) and, particularly, if indirect land-use change and loss of carbon are accounted for [123]. Use of crop residues can also lead to larger emissions of GHG from supply chains due to the allocation of part of the emissions from crop production to the residues [231]. Biomass conversion to biochar via pyrolysis usually has low emissions of GHG as syngas is used to run the conversion plant (avoiding fossil fuel input) and as biogenic carbon is usually assumed to be neutral. Transportation of feedstock and of biochar represents usually less than $10 \%$ of the GHG emissions from the supply chain $[123,231-233,238]$, even under long transportation of feedstock $[231,240]$ (e.g., from Canada to UK or from Indonesia to Australia). Fast 
pyrolysis with bio-oil upgrade to liquid fuel also leads to higher GHG emissions during the supply chain due to lower energy efficiency and more energy input required for feedstock processing [232]. Drying of wet feedstock (e.g., manures) can represent $25-83 \%$ of the supply chain's GHG emissions, particularly if heat production during pyrolysis or from coproducts is not enough to meet drying needs (requiring fossil energy) [237,246,247].

The use of forest or agricultural residues have implications for nutrient cycling and soil carbon, which are not always modeled in LCA. Wang and colleagues [232] included nutrient loss from feedstock collection, and Nguyen and colleagues [256] accounted for both nutrient and soil carbon loss, while Hammond and colleagues [231] accounted for avoided emissions during residue decomposition on forest ground. Changes in SOC stocks over consecutive years of residue removal can significantly increase the life-cycle emissions of the produced biofuels [153], and the same risks can occur for biochar production unless biochar is returned to the same field.

Avoided emissions account for saved emissions from avoided heat/electricity due to bioenergy production from pyrolysis coproducts and from fertilizer production due to higher fertilizer efficiency. Its contribution ranges from GHG emission savings of $1.13 \mathrm{tCO}_{2} \mathrm{eq} / \mathrm{t}$ feedstock to a net emission of $0.64 \mathrm{tCO}_{2} \mathrm{eq} / \mathrm{t}$ feedstock. GHG intensity of the background energy system being substituted is an important factor for controlling the size of avoided emissions. For example, Azzi and colleagues [151] found that, at a GHG intensity of the electric grid of $1 \mathrm{kgCO}_{2} \mathrm{eq} / \mathrm{kWh}$, biochar's coproducts can offset by $\sim 0.25-1 \mathrm{tCO}_{2} \mathrm{eq} / \mathrm{t}$ feedstock while, at $0.2 \mathrm{kgCO}_{2} \mathrm{eq} / \mathrm{kWh}$, the offsets are only $\sim 0.1-0.25 \mathrm{tCO}_{2} \mathrm{eq} / \mathrm{t}$ feedstock. The positive values under 'avoided emissions' in Figure 3 occur when pyrolysis replaces waste treatments that save large amounts of GHG emissions (for example, recycling of cardboard), so that diverting the waste stream results in less avoided emissions overall [152]. Wood contains more energy than herbaceous feedstock, leading to higher fossil fuel savings due to higher bioenergy production ( $\sim 25-38 \%$ increase from crop to wood residues) [231]. Large-scale plants have lower energy losses, leading to higher energy output and fossil fuel savings ( $122-150 \%$ increase from plant treating 2000 to treating 100,000 tonnes of feedstock per year) [231]. Increasing pyrolysis temperature decreases biochar yield and increases bio-oil and syngas yields; 3.75 more energy is recoverable at 600 compared to $300{ }^{\circ} \mathrm{C}$ [247].

Some LCA studies compare biochar systems to alternative uses of the same feedstock. For example, Clare and colleagues [236] showed that using straw residues for gasification or coal briquettes leads to higher climate change mitigation potentials than biochar in China due to larger offsets of fossil energy. Other studies $[69,151,253]$ reach similar conclusion with standard bioenergy systems achieving more climate benefit compared to biochar sequestration. As a general interpretation, larger climate benefits from using residues for biochar production are achieved in regions with low carbon intensity energy systems, whereas in regions with high carbon intensive energy systems, the use of residues for bioenergy is a better option as it can bring the largest emission savings.

Carbon sequestration accounts for biochar sequestration in soils, and the variation in the results is mostly due to different assumptions of biochar stability. As seen in Table 4, some studies assume a carbon labile fraction of 30\% [251,254], 20\% [123,236-238], or 15\% [69,152,231,232]. Some studies then assume a mean residence time (MRT; between 200-500 years [69,231-233]) of biochar and integrate the loss over 100 years $[69,231-233]$. Other studies assume that only the labile fraction is degraded to $\mathrm{CO}_{2}[236,251]$. In Figure 3, higher biochar stability means more carbon sequestration. However, there is a large difference between the assumption of stable carbon in LCA studies and the 3\%/97\% split noted by Wang and colleagues, which is based on a meta-analysis of field/laboratory experiments [20]. This may be due to a lack of compiled carbon stability data at the time of the LCA studies as the meta-analysis of biochar stability are from 2016 and 2018 [18,20] or to a choice of keeping conservative assumptions. Thers and colleagues [249] showed that carbon sequestration is increased at higher pyrolysis temperature by $10 \%$ from $400{ }^{\circ} \mathrm{C}$ to $800{ }^{\circ} \mathrm{C}$.

Rapid decomposition of the labile fraction of biochar and burning of bio-oil/syngas leads to carbon emissions that can happen before biomass had time to regrow. This delay between emission of biogenic 
carbon and biomass regrowth leads to a temporary increase in atmospheric carbon concentration that has a warming effect $[261,262]$. This temporary effect is found to reduce the climate benefits of biochar systems of small round wood (regrowth cycle 50 years) and crop residues (regrowth over one year) by about $15 \%$ [69].

Effects on soils account for biochar's effects on soil emissions, soil albedo, and native SOC. Biochar effects on soil emissions are usually modeled crudely and are likely to depend on local soil conditions. Reduction in soil $\mathrm{N}_{2} \mathrm{O}$ emissions account for about $1.5-4 \%[123,232,233,252]$ of the total climate mitigation of biochar. Changes in soil $\mathrm{CH}_{4}$ emissions/uptake have a warming effect of $-1.1 \%$ to a cooling effect of $+9 \%$ of the overall climate impacts [151,252]. Azzi and colleagues [151] found that biochar can reduce GHG emissions up to $14-23 \%$ of its total mitigation contribution. They modeled a cascading effect of biochar, where it is used as cattle feed addition (lowering enteric methane emissions) and is added to manures during storage (lowering $\mathrm{N}_{2} \mathrm{O}, \mathrm{CH}_{4}$, and $\mathrm{NH}_{3}$ emissions) before its land application (lowering $\mathrm{N}_{2} \mathrm{O}$ emissions). Reduced soil albedo decreases climate mitigation benefits by $13-22 \%$ [69].

Aspects like changes in soil albedo, evapotraspiration, and NTCFs emissions are difficult to quantify, and an estimation of the climate effects usually requires coupled land-atmosphere climate models to account for complex interactions between precipitations and latent heat, surface radiation, and clouds $[263,264]$. NTCFs have very short lifetime in the atmosphere, leading to spatially heterogeneous concentrations, and affect climate forcing through multiple pathways, making their effects on climate uncertain [64]. As such, those effects are not streamlined in the LCA methodology but can be included in some specific case studies. For example, References $[265,266]$ showed that albedo effect can be significant, offseting partially or even completely the lifecycle GHG emissions of biofuel production. Arvesen and colleagues [267] found that albedo changes and that cooling aerosols offset $60-70 \%$ of life-cycle GHG emissions of boreal foerest bioenergy. In addition, changes in evapotranspiration from conversion from annual to perenial cropping systems can offset $0.5^{\circ} \mathrm{C}$ of warming, according to Georgescu and colleagues [266].

The various assumptions and modeling approaches lead to a large variation in the overall climate change mitigation potential of biochar (see 'Total' in Figure 3). Some studies found an overall warming potential of biochar despite the amount of carbon added to soils. These studies $[239,240,242]$ do not consider carbon abatement from pyrolysis coproducts and do not consider low biochar yield and stability. Looking at the total, appreciation of the carbon abatement differences between the feedstocks is easier, with usually the lowest climate change mitigation potential for organic wastes, followed by herbaceous and higher climate change mitigation potential for woody materials. The largest climate change mitigation potentials are found for woody feedstock and low pyrolysis temperature $\left(\sim 300^{\circ} \mathrm{C}\right)[238,247]$. However, these two studies suffer from incomplete modeling of the effect of pyrolysis temperature on biochar stability. Their results must be contrasted by results from Thers and colleagues [249], who found a higher climate mitigation potential for high temperature biochar in their more thorough modeling of the effect of pyrolysis temperature (decrease in biochar yield but increase in biochar's carbon content and its stability and increase in bio-oil yield).

In terms of other LCA impact categories, some LCA studies focus on mid-point indicators and other go to end-points (Table S14). Pyrolysis systems for energy and biochar application to soils are found to have lower negative effects on human toxicity and eutrophication categories due to lower fertilizer and natural gas use $[238,256]$. Management of dedicated feedstock plantation for biochar production can increase risks of acidification and eutrophication and, therefore, on ecosystem quality due to use of fossil fuel in machinery, fertilizers, and pesticides [237,241]. Biochar produced from miscanthus plantation is found to provide only benefits in terms of climate change [260]. Handling of sewage sludge with biochar production and land application reduces the risks associated with their incineration and further landfilling or land application of their ashes, such as reduced aquatic ecotoxicity, carcinogenic and noncarcinogenic toxicity, acidification, and terrestrial ecotoxicity [244,245]. Biochar liming effect, lower fertilization need, and immobilization of heavy-metals in biochar 
are the mechanisms behind the reduced environmental load. In terms of end-points, energy requirements for drying is an important contributor of degradation of ecosystem ecosystem quality and human health [237]. Traditional kilns for biochar production can also present a risk for human toxicity via increased particulate matter exposition [257-259].

However, not all effects of biochar on soil are modeled, as discussed in Section 4. Nitrogen emissions are important for ecosystem quality and human health, but effects of biochar on soil $\mathrm{NO}_{x}$ and $\mathrm{NH}_{3}$ are not modeled. Leaching of nutrients are reduced but only via the indirect effect of the reduced need for fertilizer and not because of higher retention due to biochar addition.

Some LCA studies take into account the positive effect of biochar on yields. Choosing the functional unit as unit of food or unit of land, they implicitly model biochar's yield effect, as environmental impacts become divided over larger output [251,257]. Peters and colleagues modeled climate change mitigation potential of short-rotation coppice for biochar production using a functional unit per unit of area [241]. Biochar is reapplied to the plantation, increasing yield and biomass output and further improving the plantation climate mitigation potential. Two studies also model biochar's effect on NPP by assuming that it would increase accumulation of plant carbon in soils $[152,231]$.

\section{Biochar and Social and Ethical Aspects}

Justice is at the heart of mitigating climate change, whether it is to protect future generations from unstable, extreme climate or to protect the most vulnerable that have less responsibility in global warming but may suffer the most consequences. Technologies aiming at limiting warming are also subject to a set of ethical considerations, among them fairness and justice [268]. An aspect that is particularly important is the distribution of potential burden of deploying certain technologies, especially toward the most vulnerable populations.

Negative emission technologies are subject to multiple ethical considerations. Among NETs, biochar is one with the lowest ethical side effects. Low input agriculture on small-scale farms is widespread in tropical and subtropical regions [15]. Yield response to biochar is more pronounced in those regions with weathered soils [29]. Biochar may provide important social benefits for some of the most vulnerable farmers. Higher soil water retention may also provide adaptation to climate change in some of the most vulnerable regions. Higher yield and retention of soil fertility may also help mitigate shifting agriculture practices in tropical forests, which is responsible for about $24 \%$ of forest disturbances [269].

In terms of its deployment being a local practice, it is possible to develop strategies and protocols where it can be applied only when negative side effects are reduced. There is a risk that a large-scale deployment of biochar technologies, such as at the scales required by several climate change mitigation scenarios, can have adverse side effects on food security or natural ecosystems due to expansion of dedicated biomass plantations for biochar feedstocks at expenses of croplands or forests. Cross-sectoral integrated policies should ensure that future growth of a biochar market would not lead to competition with food production or trigger deforestation. Further, biochar is intended to remain decades or even centuries in soils, and its long-term aging and effects on soils are not fully understood. Removing biochar once in soils seems hypothetical and would require important soil disturbance.

\section{Conclusions}

In this review study, we discussed implications of biochar application to soils around three areas of concern: climate, food security, and ecosystem and toxicity. We provided some key controlling factors regarding biochar effects on those areas of concern. However, most of the identified patterns on biochar's effects on soil are gathered from meta-analyses, which sometimes may suffer from methodological issues, such as combined nonindependent data points, raising question of pseudo-replications that may have overestimated or increased the confidence of some effects of biochar in soils $[36,38,270,271]$. 
Biochar is an attractive NET for CDR as it can supply two marketable products, biochar as soil amendment and bioenergy generation via biochar coproducts (bio-oil and syngas). Pyrolysis is a rather simple, known technology that can be deployed in both developed economies and developing countries. More agricultural benefits associated with biochar systems are expected in developing countries with low agricultural inputs and degraded/weathered soils. Low investment potential can limit the additional climate mitigation benefits from bioenergy production as it requires more infrastructure to recover, produce, and distribute energy. On the other hand, developed economies in temperate regions may expect less agricultural benefits from biochar application to soils, but higher level of investment can allow to avoid fossil energy use and to provide incentives for negative emissions.

Climate change mitigation benefits of biochar are potentially large but depend on soil interactions, its production conditions, availability of cheap and sustainable feedstocks, and management practices. As another biomass-based NET, biochar supply is constrained by the availability of forest or crop residues or of land to grow dedicated bioenergy crops. Interactions of biochar with the climate systems are more complex than carbon sequestration only or reductions in GHG emissions from soils. They include changes in surface albedo, soil water fluxes, and emissions of NTCFs, which are difficult to quantify and affect the estimates of net local and global climate effects of biochar systems.

Some aspects of biochar needs further investigation. Potential emissions of black carbon from soil after biochar application would have implications for climate mitigation and toxicity, and the availability of specific emission factors would facilitate their inclusion in environmental assessment studies. Leaching of dissolved biochar carbon and its degradation in water systems could decrease its long-term sequestration potential while being toxic. Interactions between the biophysical and biogeochemical effects of biochar in soils are highly complex. Future integration of biochar deployment scenarios with climate models of varying complexity can offer an opportunity to quantify biochar's climate interactions in full and can distill simplified metrics to be used in individual studies aiming at assessing the role of biochar for climate change mitigation and adaptation in different geographical contexts and for different feedstock-application combinations.

Supplementary Materials: The following are available online at http:/ /www.mdpi.com/2073-445X/8/12/179/s1, Table S1: Main controlling factors on the effect of biochar on agricultural yield; Table S2: Main controlling factors on the effect of biochar on soil and exposition to toxic compounds; Table S3: CDR requirements for different temperature pathways; Table S4: Total cumulative CDR requirements for different temperature pathways; Table S5: Key biochar properties and their controlling factors under slow pyrolysis; Table S6: Main controlling factors of the effect of biochar on SOC priming; Table S7: Main controlling factors of the effect of biochar on soil methane $\left(\mathrm{CH}_{4}\right)$ emissions or uptake; Table S8: Main controlling factors on the effect of biochar on soil nitrogen availability; Table S9: Main controlling factors of the effect of biochar on soil ammonia $\left(\mathrm{NH}_{3}\right)$ volatilization rate; Table S10: Main controlling factors on the effect of biochar on soil phosphorus availability; Table S11: Main controlling factors on the effect of biochar on soil nutrient leaching; Table S12: Main controlling factors on the effect of biochar on soil water availability and soil hydraulic conductivity; Table S13: Classification of the LCA studies under type of feedstock and origin (residue, dedicated plantations, or waste) of which the life-cycle stage results were used in Figure 3 in the main text; Table S14: Classification of LCA studies according to the type of impact/indicator they include in the analysis.

Author Contributions: Conceptualization, F.C.; investigation, A.T.; writing-original draft preparation, A.T.; writing-review and editing, F.C.; visualization, A.T.; supervision, F.C.; project administration, F.C.; funding acquisition, F.C.

Funding: This research is part of the project CARBO-FERTIL, funded by the Norwegian Research Council (Norges Forskningsråd), grant number 281113.

Acknowledgments: The authors thank the reviewers and the editors for helpful comments.

Conflicts of Interest: The authors declare no conflict of interest. 


\section{Abbreviations}

The following abbreviations are used in this manuscript:

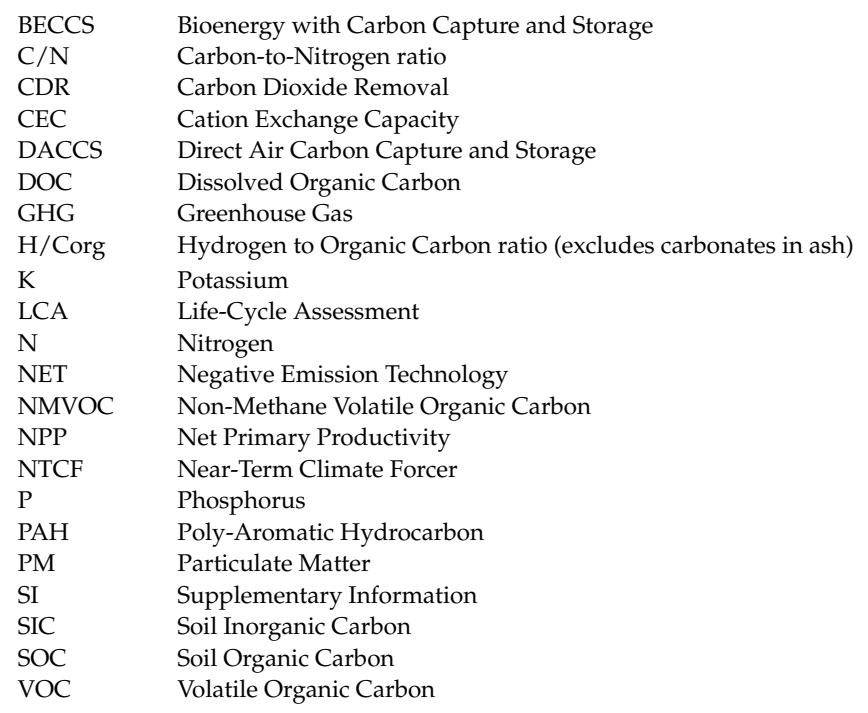

\section{References}

1. Steffen, W.; Richardson, K.; Rockström, J.; Cornell, S.E.; Fetzer, I.; Bennett, E.M.; Biggs, R.; Carpenter, S.R.; de Vries, W.; de Wit, C.A.; et al. Planetary boundaries: Guiding human development on a changing planet. Science 2015, 347, 1259855. [CrossRef] [PubMed]

2. Steffen, W.; Rockström, J.; Richardson, K.; Lenton, T.M.; Folke, C.; Liverman, D.; Summerhayes, C.P.; Barnosky, A.D.; Cornell, S.E.; Crucifix, M.; et al. Trajectories of the Earth System in the Anthropocene. Proc. Natl. Acad. Sci. USA 2018, 115, 8252-8259. [CrossRef] [PubMed]

3. United Nations. Paris Agreement; Technical Report; United Nations: New York, NY, USA, 2015.

4. Van Vuuren, D.P.; Stehfest, E.; Gernaat, D.E.H.J.; Berg, M.V.D.; Bijl, D.L.; Boer, H.S.D.; Daioglou, V.; Doelman, J.C.; Edelenbosch, O.Y.; Harmsen, M.; et al. Alternative pathways to the $1.5^{\circ} \mathrm{C}$ target reduce the need for negative emission technologies. Nat. Clim. Chang. 2018, 8, 391. [CrossRef]

5. Minx, J.C.; Lamb, W.F.; Callaghan, M.W.; Fuss, S.; Hilaire, J.; Creutzig, F.; Thorben, A.; Beringer, T.; Garcia, W.D.O.; Hartmann, J.; et al. Negative emissions-Part 1: Research landscape and synthesis. Environ. Res. Lett. 2018, 13, 063001. [CrossRef]

6. Boysen, L.R.; Lucht, W.; Gerten, D.; Heck, V.; Lenton, T.M.; Schellnhuber, H.J. The limits to global-warming mitigation by terrestrial carbon removal. Earth's Future 2017, 5, 463-474. [CrossRef]

7. Heck, V.; Gerten, D.; Lucht, W.; Popp, A. Biomass-based negative emissions difficult to reconcile with planetary boundaries. Nat. Clim. Chang. 2018, 8, 151. [CrossRef]

8. Lawrence, M.G.; Schäfer, S.; Muri, H.; Scott, V.; Oschlies, A.; Vaughan, N.E.; Boucher, O.; Schmidt, H.; Haywood, J.; Scheffran, J. Evaluating climate geoengineering proposals in the context of the Paris Agreement temperature goals. Nat. Commun. 2018, 9, 3734. [CrossRef]

9. Lehmann, J.; Gaunt, J.; Rondon, M. Bio-char sequestration in terrestrial ecosystems-A review. Mitig. Adapt. Strateg. Glob. Chang. 2006, 11, 403-427. [CrossRef]

10. IPCC. Chapter 4: Land Degradation. In Special Report on Climate Change and Land; IPCC: Geneva, Switzerland, 2019; p. 186.

11. Ippolito, J.A.; Laird, D.A.; Busscher, W.J. Environmental Benefits of Biochar. J. Environ. Qual. 2012, 41, 967. [CrossRef]

12. Meyer, S.; Glaser, B.; Quicker, P. Technical, Economical, and Climate-Related Aspects of Biochar Production Technologies: A Literature Review. Environ. Sci. Technol. 2011, 45, 9473-9483. [CrossRef]

13. Zhang, C.; Zeng, G.; Huang, D.; Lai, C.; Chen, M.; Cheng, M.; Tang, W.; Tang, L.; Dong, H.; Huang, B.; et al. Biochar for environmental management: Mitigating greenhouse gas emissions, contaminant treatment, and potential negative impacts. Chem. Eng. J. 2019, 373, 902-922. [CrossRef] 
14. Smith, P. Soil carbon sequestration and biochar as negative emission technologies. Glob. Chang. Biol. 2016, 22, 1315-1324. [CrossRef] [PubMed]

15. Nair, V.D.; Nair, P.K.R.; Dari, B.; Freitas, A.M.; Chatterjee, N.; Pinheiro, F.M. Biochar in the Agroecosystem-Climate-Change-Sustainability Nexus. Front. Plant Sci. 2017, 8. [CrossRef] [PubMed]

16. Fuss, S.; Lamb, W.F.; Callaghan, M.W.; Hilaire, J.; Creutzig, F.; Amann, T.; Beringer, T.; Garcia, W.d.O.; Hartmann, J.; Khanna, T.; et al. Negative emissions-Part 2: Costs, potentials and side effects. Environ. Res. Lett. 2018, 13, 063002. [CrossRef]

17. Schmidt, H.P.; Anca-Couce, A.; Hagemann, N.; Werner, C.; Gerten, D.; Lucht, W.; Kammann, C. Pyrogenic carbon capture and storage. GCB Bioenergy 2018, [CrossRef]

18. Chao, L.; Zhang, W.D.; Wang, S.L. Understanding the dominant controls on biochar decomposition using boosted regression trees. Eur. J. Soil Sci. 2018, 69, 512-520. [CrossRef]

19. Ding, F.; Van Zwieten, L.; Zhang, W.; Weng, Z.; Shi, S.; Wang, J.; Meng, J. A meta-analysis and critical evaluation of influencing factors on soil carbon priming following biochar amendment. J. Soils Sediments 2018, 18, 1507-1517. [CrossRef]

20. Wang, J.; Xiong, Z.; Kuzyakov, Y. Biochar stability in soil: Meta-analysis of decomposition and priming effects. GCB Bioenergy 2016, 8, 512-523. [CrossRef]

21. Mia, S.; Dijkstra, F.; Singh, B. Long-Term Aging of Biochar. In Advances in Agronomy; Elsevier: Amsterdam, The Netherlands, 2017; Volume 141, pp. 1-51. [CrossRef]

22. Blanco-Canqui, H. Biochar and Soil Physical Properties. Soil Sci. Soc. Am. J. 2017, 81, 687. [CrossRef]

23. Blanco-Canqui, H. Biochar and Water Quality. J. Environ. Qual. 2018, 48, 2. [CrossRef]

24. Omondi, M.O.; Xia, X.; Nahayo, A.; Liu, X.; Korai, P.K.; Pan, G. Quantification of biochar effects on soil hydrological properties using meta-analysis of literature data. Geoderma 2016, 274, 28-34. [CrossRef]

25. Fischer, B.M.C.; Manzoni, S.; Morillas, L.; Garcia, M.; Johnson, M.S.; Lyon, S.W. Improving agricultural water use efficiency with biochar-A synthesis of biochar effects on water storage and fluxes across scales. Sci. Total Environ. 2019, 657, 853-862. [CrossRef] [PubMed]

26. Al-Wabel, M.I.; Hussain, Q.; Usman, A.R.; Ahmad, M.; Abduljabbar, A.; Sallam, A.S.; Ok, Y.S. Impact of biochar properties on soil conditions and agricultural sustainability: A review. Land Degrad. Dev. 2018, 29, 2124-2161. [CrossRef]

27. Palansooriya, K.N.; Ok, Y.S.; Awad, Y.M.; Lee, S.S.; Sung, J.K.; Koutsospyros, A.; Moon, D.H. Impacts of biochar application on upland agriculture: A review. J. Environ. Manag. 2019, 234, 52-64. [CrossRef] [PubMed]

28. Crane-Droesch, A.; Abiven, S.; Jeffery, S.; Torn, M.S. Heterogeneous global crop yield response to biochar: A meta-regression analysis. Environ. Res. Lett. 2013, 8. [CrossRef]

29. Jeffery, S.; Abalos, D.; Prodana, M.; Bastos, A.C.; Van Groenigen, J.W.; Hungate, B.A.; Verheijen, F. Biochar boosts tropical but not temperate crop yields. Environ. Res. Lett. 2017, 12, [CrossRef]

30. Ding, Y.; Liu, Y.; Liu, S.; Huang, X.; Li, Z.; Tan, X.; Zeng, G.; Zhou, L. Potential Benefits of Biochar in Agricultural Soils: A Review. Pedosphere 2017, 27, 645-661. [CrossRef]

31. Kavitha, B.; Reddy, P.V.L.; Kim, B.; Lee, S.S.; Pandey, S.K.; Kim, K.H. Benefits and limitations of biochar amendment in agricultural soils: A review. J. Environ. Manag. 2018, 227, 146-154. [CrossRef]

32. Agegnehu, G.; Srivastava, A.K.; Bird, M.I. The role of biochar and biochar-compost in improving soil quality and crop performance: A review. Appl. Soil Ecol. 2017, 119, 156-170. [CrossRef]

33. He, Y.; Zhou, X.; Jiang, L.; Li, M.; Du, Z.; Zhou, G.; Shao, J.; Wang, X.; Xu, Z.; Hosseini Bai, S.; et al. Effects of biochar application on soil greenhouse gas fluxes: A meta-analysis. GCB Bioenergy 2017, 9, 743-755. [CrossRef]

34. Liu, X.; Mao, P.; Li, L.; Ma, J. Impact of biochar application on yield-scaled greenhouse gas intensity: A meta-analysis. Sci. Total Environ. 2019, 656, 969-976. [CrossRef] [PubMed]

35. Ji, C.; Jin, Y.; Li, C.; Chen, J.; Kong, D.; Yu, K.; Liu, S.; Zou, J. Variation in Soil Methane Release or Uptake Responses to Biochar Amendment: A Separate Meta-analysis. Ecosystems 2018, 21, 1692-1705. [CrossRef]

36. Cong, W.; Meng, J.; Ying, S.C. Impact of soil properties on the soil methane flux response to biochar addition: A meta-analysis. Biogeosci. Discuss. 2018, 20, 1-31. [CrossRef] [PubMed] 
37. Borchard, N.; Schirrmann, M.; Cayuela, M.L.; Kammann, C.; Wrage-Mönnig, N.; Estavillo, J.M.; Fuertes-Mendizábal, T.; Sigua, G.; Spokas, K.; Ippolito, J.A.; et al. Biochar, soil and land-use interactions that reduce nitrate leaching and N2O emissions: A meta-analysis. Sci. Total Environ. 2019, 651, 2354-2364. [CrossRef]

38. Verhoeven, E.; Pereira, E.; Decock, C.; Suddick, E.; Angst, T.; Six, J. Toward a Better Assessment of Biochar-Nitrous Oxide Mitigation Potential at the Field Scale. J. Environ. Qual. 2017, 46, 237. [CrossRef]

39. Cayuela, M.L.; Jeffery, S.; van Zwieten, L. The molar H:Corg ratio of biochar is a key factor in mitigating $\mathrm{N}_{2} \mathrm{O}$ emissions from soil. Agric. Ecosyst. Environ. 2015, 202, 135-138. [CrossRef]

40. Cayuela, M.L.; van Zwieten, L.; Singh, B.P.; Jeffery, S.; Roig, A.; Sánchez-Monedero, M.A. Biochar's role in mitigating soil nitrous oxide emissions: A review and meta-analysis. Agric. Ecosyst. Environ. 2014, 191, 5-16. [CrossRef]

41. Jeffery, S.; Verheijen, F.G.; Kammann, C.; Abalos, D. Biochar effects on methane emissions from soils: A meta-analysis. Soil Biol. Biochem. 2016, 101, 251-258. [CrossRef]

42. Schirrmann, M.; Cayuela, M.L.; Fuertes-Mendizábal, T.; Estavillo, J.M.; Ippolito, J.; Spokas, K.; Novak, J.; Kammann, C.; Wrage-Mönnig, N.; Borchard, N. Biochar reduces $\mathrm{N}_{2} \mathrm{O}$ emissions from soils: A meta-analysis. In Proceedings of the 19th EGU General Assembly, EGU2017, Vienna, Austria, 23-28 April 2017; Volume 19, p. 8265.

43. Zhou, H.; Zhang, D.; Wang, P.; Liu, X.; Cheng, K.; Li, L.; Zheng, J.; Zhang, X.; Zheng, J.; Crowley, D.; et al. Changes in microbial biomass and the metabolic quotient with biochar addition to agricultural soils: A Meta-analysis. Agric. Ecosyst. Environ. 2017, 239, 80-89. [CrossRef]

44. Song, X.; Pan, G.; Zhang, C.; Zhang, L.; Wang, H. Effects of biochar application on fluxes of three biogenic grenhouse gases: A meta-analysis. Ecosyst. Health Sustain. 2016, 2, e01202. [CrossRef]

45. Liu, Q.; Liu, B.; Zhang, Y.; Hu, T.; Lin, Z.; Liu, G.; Wang, X.; Ma, J.; Wang, H.; Jin, H.; et al. Biochar application as a tool to decrease soil nitrogen losses $\left(\mathrm{NH}_{3}\right.$ volatilization, $\mathrm{N}_{2} \mathrm{O}$ emissions, and $\mathrm{N}$ leaching) from croplands: Options and mitigation strength in a global perspective. Glob. Chang. Biol. 2019. [CrossRef] [PubMed]

46. Liu, Q.; Zhang, Y.; Liu, B.; Amonette, J.E.; Lin, Z.; Liu, G.; Ambus, P.; Xie, Z. How does biochar influence soil N cycle? A meta-analysis. Plant Soil 2018, 426, 211-225. [CrossRef]

47. Sha, Z.; Li, Q.; Lv, T.; Misselbrook, T.; Liu, X. Response of ammonia volatilization to biochar addition: A meta-analysis. Sci. Total Environ. 2019, 655, 1387-1396. [CrossRef] [PubMed]

48. Gao, S.; DeLuca, T.H.; Cleveland, C.C. Biochar additions alter phosphorus and nitrogen availability in agricultural ecosystems: A meta-analysis. Sci. Total Environ. 2019, 654, 463-472. [CrossRef] [PubMed]

49. Gul, S.; Whalen, J.K. Biochemical cycling of nitrogen and phosphorus in biochar-amended soils. Soil Biol. Biochem. 2016, 103, 1-15. [CrossRef]

50. Dai, L.; Li, H.; Tan, F.; Zhu, N.; He, M.; Hu, G. Biochar: A potential route for recycling of phosphorus in agricultural residues. GCB Bioenergy 2016, 8, 852-858. [CrossRef]

51. Dutta, T.; Kwon, E.; Bhattacharya, S.S.; Jeon, B.H.; Deep, A.; Uchimiya, M.; Kim, K.H. Polycyclic aromatic hydrocarbons and volatile organic compounds in biochar and biochar-amended soil: A review. GCB Bioenergy 2017, 9, 990-1004. [CrossRef]

52. Lian, F.; Xing, B. Black Carbon (Biochar) In Water/Soil Environments: Molecular Structure, Sorption, Stability, and Potential Risk. Environ. Sci. Technol. 2017, 51, 13517-13532. [CrossRef]

53. Hilber, I.; Bastos, A.C.; Loureiro, S.; Soja, G.; Marsz, A.; Cornelissen, G.; Bucheli, T.D. The different faces of biochar: Contamination risk versus remediation tool. J. Environ. Eng. Landsc. Manag. 2017, 25, 86-104. [CrossRef]

54. Rizwan, M.; Ali, S.; Qayyum, M.F.; Ibrahim, M.; Zia-ur Rehman, M.; Abbas, T.; Ok, Y.S. Mechanisms of biochar-mediated alleviation of toxicity of trace elements in plants: A critical review. Environ. Sci. Pollut. Res. 2016, 23, 2230-2248. [CrossRef]

55. Zama, E.F.; Reid, B.J.; Arp, H.P.H.; Sun, G.X.; Yuan, H.Y.; Zhu, Y.G. Advances in research on the use of biochar in soil for remediation: A review. J. Soils Sediments 2018, 18, 2433-2450. [CrossRef]

56. Abbas, Z.; Ali, S.; Rizwan, M.; Zaheer, I.E.; Malik, A.; Riaz, M.A.; Shahid, M.R.; Rehman, M.Z.U.; Al-Wabel, M.I. A critical review of mechanisms involved in the adsorption of organic and inorganic contaminants through biochar. Arab. J. Geosci. 2018, 11, 448. [CrossRef]

57. Yuan, P.; Wang, J.; Pan, Y.; Shen, B.; Wu, C. Review of biochar for the management of contaminated soil: Preparation, application and prospect. Sci. Total Environ. 2019, 659, 473-490. [CrossRef] [PubMed] 
58. Zhu, X.; Chen, B.; Zhu, L.; Xing, B. Effects and mechanisms of biochar-microbe interactions in soil improvement and pollution remediation: A review. Environ. Pollut. 2017, 227, 98-115. [CrossRef]

59. Chen, D.; Liu, X.; Bian, R.; Cheng, K.; Zhang, X.; Zheng, J.; Joseph, S.; Crowley, D.; Pan, G.; Li, L. Effects of biochar on availability and plant uptake of heavy metals-A meta-analysis. J. Environ. Manag. 2018, 222, 76-85. [CrossRef]

60. Liu, Y.; Lonappan, L.; Brar, S.K.; Yang, S. Impact of biochar amendment in agricultural soils on the sorption, desorption, and degradation of pesticides: A review. Sci. Total Environ. 2018, 645, 60-70. [CrossRef]

61. Safaei Khorram, M.; Zhang, Q.; Lin, D.; Zheng, Y.; Fang, H.; Yu, Y. Biochar: A review of its impact on pesticide behavior in soil environments and its potential applications. J. Environ. Sci. 2016, 44, 269-279. [CrossRef]

62. Yavari, S.; Malakahmad, A.; Sapari, N.B. Biochar efficiency in pesticides sorption as a function of production variables-A review. Environ. Sci. Pollut. Res. 2015, 22, 13824-13841. [CrossRef]

63. Mukherjee, A.; Lal, R. The biochar dilemma. Soil Res. 2014, 52, 217. [CrossRef]

64. Collins, W.J.; Fry, M.M.; Yu, H.; Fuglestvedt, J.S.; Shindell, D.T.; West, J.J. Global and regional temperature-change potentials for near-term climate forcers. Atmos. Chem. Phys. 2013, 13, 2471-2485. [CrossRef]

65. Bond, T.C.; Doherty, S.J.; Fahey, D.W.; Forster, P.M.; Berntsen, T.; DeAngelo, B.J.; Flanner, M.G.; Ghan, S.; Kärcher, B.; Koch, D.; et al. Bounding the role of black carbon in the climate system: A scientific assessment: Black Carbon in the Climate System. J. Geophys. Res. Atmos. 2013, 118, 5380-5552. [CrossRef]

66. Cornelissen, G.; Pandit, N.R.; Taylor, P.; Pandit, B.H.; Sparrevik, M.; Schmidt, H.P. Emissions and char quality of flame-curtain "Kon Tiki" kilns for farmer-scale charcoal biochar production. PLoS ONE 2016, 11, e0154617. [CrossRef] [PubMed]

67. Bonan, G. Ecological Climatology: Concepts and Applications, 3rd ed.; Cambridge University Press: Cambridge, UK, 2015.

68. Bozzi, E.; Genesio, L.; Toscano, P.; Pieri, M.; Miglietta, F. Mimicking biochar-albedo feedback in complex Mediterranean agricultural landscapes. Environ. Res. Lett. 2015, 10. [CrossRef]

69. Meyer, S.; Bright, R.M.; Fischer, D.; Schulz, H.; Glaser, B. Albedo impact on the suitability of biochar systems to mitigate global warming. Environ. Sci. Technol. 2012, 46, 12726-12734. [CrossRef]

70. Bright, R.M.; Bogren, W.; Bernier, P.; Astrup, R. Carbon-equivalent metrics for albedo changes in land management contexts: Relevance of the time dimension. Ecol. Appl. 2016, 26, 1868-1880. [CrossRef]

71. Genesio, L.; Miglietta, F.; Lugato, E.; Baronti, S.; Pieri, M.; Vaccari, F.P. Surface albedo following biochar application in durum wheat. Environ. Res. Lett. 2012, 7. [CrossRef]

72. Seneviratne, S.I.; Corti, T.; Davin, E.L.; Hirschi, M.; Jaeger, E.B.; Lehner, I.; Orlowsky, B.; Teuling, A.J. Investigating soil moisture-climate interactions in a changing climate: A review. Earth-Sci. Rev. 2010, 99, 125-161. [CrossRef]

73. Rojas, R.V.; Achouri, M.; Maroulis, J.; Caon, L. Healthy soils: A prerequisite for sustainable food security. Environ. Earth Sci. 2016, 75, 180. [CrossRef]

74. Smith, P.; House, J.I.; Bustamante, M.; Sobocká, J.; Harper, R.; Pan, G.; West, P.C.; Clark, J.M.; Adhya, T.; Rumpel, C.; et al. Global change pressures on soils from land use and management. Glob. Chang. Biol. 2016, 22, 1008-1028. [CrossRef]

75. Jeffery, S.; Verheijen, F.G.; van der Velde, M.; Bastos, A.C. A quantitative review of the effects of biochar application to soils on crop productivity using meta-analysis. Agric. Ecosyst. Environ. 2011, 144, 175-187. [CrossRef]

76. Biederman, L.A.; Harpole, W.S. Biochar and its effects on plant productivity and nutrient cycling: A meta-analysis. GCB Bioenergy 2013, 5, 202-214. [CrossRef]

77. Kerré, B.; Willaert, B.; Cornelis, Y.; Smolders, E. Long-term presence of charcoal increases maize yield in Belgium due to increased soil water availability. Eur. J. Agron. 2017, 91, 10-15. [CrossRef]

78. Hood-Nowotny, R.; Watzinger, A.; Wawra, A.; Soja, G. The Impact of Biochar Incorporation on Inorganic Nitrogen Fertilizer Plant Uptake; An Opportunity for Carbon Sequestration in Temperate Agriculture. Geosciences 2018, 8, 420. [CrossRef]

79. Lorenz, K.; Lal, R. Carbon Sequestration in Agricultural Ecosystems; Springer International Publishing: Cham, Switzerland, 2018. [CrossRef] 
80. Wang, Y.; Villamil, M.B.; Davidson, P.C.; Akdeniz, N. A quantitative understanding of the role of co-composted biochar in plant growth using meta-analysis. Sci. Total Environ. 2019, 685, 741-752. [CrossRef]

81. Kammann, C.; Graber, E.R. Biochar effects on plant ecophysiology. In Biochar for Environmental Management: Science, Technology and Implementation; Routledge: Abingdon, UK, 2015.

82. Viger, M.; Hancock, R.D.; Miglietta, F.; Taylor, G. More plant growth but less plant defence? First global gene expression data for plants grown in soil amended with biochar. GCB Bioenergy 2015, 7, 658-672. [CrossRef]

83. Polzella, A.; De Zio, E.; Arena, S.; Scippa, G.S.; Scaloni, A.; Montagnoli, A.; Chiatante, D.; Trupiano, D. Toward an understanding of mechanisms regulating plant response to biochar application. Plant Biosyst. Int. J. Deal. Asp. Plant Biol. 2018. [CrossRef]

84. Frenkel, O.; Jaiswal, A.K.; Elad, Y.; Lew, B.; Kammann, C.; Graber, E.R. The effect of biochar on plant diseases: What should we learn while designing biochar substrates? J. Environ. Eng. Landsc. Manag. 2017, 25, $105-113$. [CrossRef]

85. Nag, S.K.; Kookana, R.; Smith, L.; Krull, E.; Macdonald, L.M.; Gill, G. Poor efficacy of herbicides in biochar-amended soils as affected by their chemistry and mode of action. Chemosphere 2011, 84, 1572-1577. [CrossRef]

86. Spokas, K.A.; Novak, J.M.; Stewart, C.E.; Cantrell, K.B.; Uchimiya, M.; DuSaire, M.G.; Ro, K.S. Qualitative analysis of volatile organic compounds on biochar. Chemosphere 2011, 85, 869-882. [CrossRef]

87. Liao, S.; Pan, B.; Li, H.; Zhang, D.; Xing, B. Detecting Free Radicals in Biochars and Determining Their Ability to Inhibit the Germination and Growth of Corn, Wheat and Rice Seedlings. Environ. Sci. Technol. 2014, 48, 8581-8587. [CrossRef]

88. Pimentel, D.; Burgess, M. Soil Erosion Threatens Food Production. Agriculture 2013, 3, 443-463. [CrossRef]

89. Panagos, P.; Standardi, G.; Borrelli, P.; Lugato, E.; Montanarella, L.; Bosello, F. Cost of agricultural productivity loss due to soil erosion in the European Union: From direct cost evaluation approaches to the use of macroeconomic models. Land Degrad. Dev. 2018, 29, 471-484. [CrossRef]

90. Rickson, R.J.; Deeks, L.K.; Graves, A.; Harris, J.A.H.; Kibblewhite, M.G.; Sakrabani, R. Input constraints to food production: The impact of soil degradation. Food Secur. 2015, 7, 351-364. [CrossRef]

91. Butcher, K.; Wick, A.F.; DeSutter, T.; Chatterjee, A.; Harmon, J. Soil Salinity: A Threat to Global Food Security. Agron. J. 2016, 108, 2189. [CrossRef]

92. Ali, S.; Rizwan, M.; Qayyum, M.F.; Ok, Y.S.; Ibrahim, M.; Riaz, M.; Arif, M.S.; Hafeez, F.; Al-Wabel, M.I.; Shahzad, A.N. Biochar soil amendment on alleviation of drought and salt stress in plants: A critical review. Environ. Sci. Pollut. Res. 2017, 24, 12700-12712. [CrossRef]

93. Dahlawi, S.; Naeem, A.; Rengel, Z.; Naidu, R. Biochar application for the remediation of salt-affected soils: Challenges and opportunities. Sci. Total Environ. 2018, 625, 320-335. [CrossRef]

94. Goulding, K.W.T. Soil acidification and the importance of liming agricultural soils with particular reference to the United Kingdom. Soil Use Manag. 2016, 32, 390-399. [CrossRef]

95. Dai, Z.; Zhang, X.; Tang, C.; Muhammad, N.; Wu, J.; Brookes, P.C.; Xu, J. Potential role of biochars in decreasing soil acidification-A critical review. Sci. Total Environ. 2017, 581-582, 601-611. [CrossRef]

96. Fidel, R.B.; Laird, D.A.; Thompson, M.L.; Lawrinenko, M. Characterization and quantification of biochar alkalinity. Chemosphere 2017, 167, 367-373. [CrossRef]

97. Qiu, M.; Sun, K.; Jin, J.; Han, L.; Sun, H.; Zhao, Y.; Xia, X.; Wu, F.; Xing, B. Metal/metalloid elements and polycyclic aromatic hydrocarbon in various biochars: The effect of feedstock, temperature, minerals, and properties. Environ. Pollut. 2015, 206, 298-305. [CrossRef]

98. Ruan, X.; Sun, Y.; Du, W.; Tang, Y.; Liu, Q.; Zhang, Z.; Doherty, W.; Frost, R.L.; Qian, G.; Tsang, D.C.W. Formation, characteristics, and applications of environmentally persistent free radicals in biochars: A review. Bioresour. Technol. 2019, 281, 457-468. [CrossRef] [PubMed]

99. Galloway, J.N.; Aber, J.D.; Erisman, J.W.; Seitzinger, S.P.; Howarth, R.W.; Cowling, E.B.; Cosby, B.J. The Nitrogen Cascade. BioScience 2003, 53, 341. [CrossRef]

100. Tian, D.; Niu, S. A global analysis of soil acidification caused by nitrogen addition. Environ. Res. Lett. 2015, 10, 024019. [CrossRef]

101. Pourhashem, G.; Rasool, Q.Z.; Zhang, R.; Medlock, K.B.; Cohan, D.S.; Masiello, C.A. Valuing the Air Quality Effects of Biochar Reductions on Soil NO Emissions. Environ. Sci. Technol. 2017, 51, 9856-9863. [CrossRef]

102. Kanakidou, M.; Myriokefalitakis, S.; Tsigaridis, K. Aerosols in atmospheric chemistry and biogeochemical cycles of nutrients. Environ. Res. Lett. 2018, 13, 063004. [CrossRef] 
103. Mahowald, N.M.; Scanza, R.; Brahney, J.; Goodale, C.L.; Hess, P.G.; Moore, J.K.; Neff, J. Aerosol Deposition Impacts on Land and Ocean Carbon Cycles. Curr. Clim. Chang. Rep. 2017, 3, 16-31. [CrossRef]

104. Stevens, C.J.; Manning, P.; van den Berg, L.J.L.; de Graaf, M.C.C.; Wamelink, G.W.W.; Boxman, A.W.; Bleeker, A.; Vergeer, P.; Arroniz-Crespo, M.; Limpens, J.; et al. Ecosystem responses to reduced and oxidised nitrogen inputs in European terrestrial habitats. Environ. Pollut. 2011, 159, 665-676. [CrossRef]

105. Sparrevik, M.; Cornelissen, G.; Sparrevik, M.; Adam, C.; Martinsen, V.; Cornelissen, G. Emissions of gases and particles from charcoal/biochar production in rural areas using medium-sized traditional and improved "retort" kilns. Biomass Bioenergy 2015, 72, 65-73. [CrossRef]

106. Cordella, M.; Torri, C.; Adamiano, A.; Fabbri, D.; Barontini, F.; Cozzani, V. Bio-oils from biomass slow pyrolysis: A chemical and toxicological screening. J. Hazard. Mater. 2012, 231-232, 26-35. [CrossRef]

107. Gelardi, D.L.; Li, C.; Parikh, S.J. An emerging environmental concern: Biochar-induced dust emissions and their potentially toxic properties. Sci. Total Environ. 2019, 678, 813-820. [CrossRef]

108. Smith, V.H.; Joye, S.B.; Howarth, R.W. Eutrophication of freshwater and marine ecosystems. Limnol. Oceanogr. 2006, 51, 351-355. [CrossRef]

109. Gao, X.; Wu, H. Aerodynamic Properties of Biochar Particles: Effect of Grinding and Implications. Environ. Sci. Technol. Lett. 2014, 1, 60-64. [CrossRef]

110. Spokas, K.A.; Novak, J.M.; Masiello, C.A.; Johnson, M.G.; Colosky, E.C.; Ippolito, J.A.; Trigo, C. Physical Disintegration of Biochar: An Overlooked Process. Environ. Sci. Technol. Lett. 2014, 1, 326-332. [CrossRef]

111. Ravi, S.; Sharratt, B.S.; Li, J.; Olshevski, S.; Meng, Z.; Zhang, J. Particulate matter emissions from biochar-amended soils as a potential tradeoff to the negative emission potential. Sci. Rep. 2016, 6, 35984. [CrossRef]

112. Li, C.; Bair, D.A.; Parikh, S.J. Estimating potential dust emissions from biochar amended soils under simulated tillage. Sci. Total Environ. 2018, 625, 1093-1101. [CrossRef]

113. Evans, C.D.; Monteith, D.T.; Cooper, D.M. Long-term increases in surface water dissolved organic carbon: Observations, possible causes and environmental impacts. Environ. Pollut. 2005, 137, 55-71. [CrossRef]

114. Lipczynska-Kochany, E. Effect of climate change on humic substances and associated impacts on the quality of surface water and groundwater: A review. Sci. Total Environ. 2018, 640-641, 1548-1565. [CrossRef]

115. Liu, C.; Wang, H.; Li, P.; Xian, Q.; Tang, X. Biochar's impact on dissolved organic matter (DOM) export from a cropland soil during natural rainfalls. Sci. Total Environ. 2019, 650, 1988-1995. [CrossRef]

116. Fu, H.; Liu, H.; Mao, J.; Chu, W.; Li, Q.; Alvarez, P.J.J.; Qu, X.; Zhu, D. Photochemistry of Dissolved Black Carbon Released from Biochar: Reactive Oxygen Species Generation and Phototransformation. Environ. Sci. Technol. 2016, 50, 1218-1226. [CrossRef]

117. Wagner, S.; Jaffé, R.; Stubbins, A. Dissolved black carbon in aquatic ecosystems. Limnol. Oceanogr. Lett. 2018, 3, 168-185. [CrossRef]

118. Khan, A.; Khan, S.; Khan, M.A.; Qamar, Z.; Waqas, M. The uptake and bioaccumulation of heavy metals by food plants, their effects on plants nutrients, and associated health risk: A review. Environ. Sci. Pollut. Res. 2015, 22, 13772-13799. [CrossRef] [PubMed]

119. Thompson, L.A.; Darwish, W.S. Environmental Chemical Contaminants in Food: Review of a Global Problem. J. Toxicol. 2019, 2019. [CrossRef] [PubMed]

120. Hale, S.E.; Lehmann, J.; Rutherford, D.; Zimmerman, A.R.; Bachmann, R.T.; Shitumbanuma, V.; O’Toole, A.; Sundqvist, K.L.; Arp, H.P.H.; Cornelissen, G. Quantifying the Total and Bioavailable Polycyclic Aromatic Hydrocarbons and Dioxins in Biochars. Environ. Sci. Technol. 2012, 46, 2830-2838. [CrossRef] [PubMed]

121. Ghidotti, M.; Fabbri, D.; Hornung, A. Profiles of Volatile Organic Compounds in Biochar: Insights into Process Conditions and Quality Assessment. ACS Sustain. Chem. Eng. 2017, 5, 510-517. [CrossRef]

122. Kookana, R.S. The role of biochar in modifying the environmental fate, bioavailability, and efficacy of pesticides in soils: A review. Soil Res. 2010, 48, 627-637. [CrossRef]

123. Roberts, K.G.; Gloy, B.A.; Joseph, S.; Scott, N.R.; Lehmann, J. Life Cycle Assessment of Biochar Systems: Estimating the Energetic , Economic, and Climate Change Potential. Environ. Sci. Technol. 2010, 44, 827-833, [CrossRef]

124. Pratt, K.; Moran, D. Evaluating the cost-effectiveness of global biochar mitigation potential. Biomass Bioenergy 2010, 34, 1149-1158. [CrossRef]

125. Woolf, D.; Amonette, J.E.; Street-Perrott, A.F.; Lehmann, J.; Joseph, S. Sustainable biochar to mitigate global climate change. Nat. Commun. 2010, 1, 56. [CrossRef] 
126. Powell, T.W.R.; Lenton, T.M. Future carbon dioxide removal via biomass energy constrained by agricultural efficiency and dietary trends. Energy Environ. Sci. 2012, 5, 8116. [CrossRef]

127. Lee, J.W.; Hawkins, B.; Day, D.M.; Reicosky, D.C. Sustainability: The capacity of smokeless biomass pyrolysis for energy production, global carbon capture and sequestration. Energy Environ. Sci. 2010, 3, 1695-1705. [CrossRef]

128. Laird, D.A.; Brown, R.C.; Amonette, J.E.; Lehmann, J. Review of the pyrolysis platform for coproducing bio-oil and biochar. Biofuels Bioprod. Biorefining 2009, 3, 547-562. [CrossRef]

129. Holz, C.; Siegel, L.S.; Johnston, E.; Jones, A.P.; Sterman, J. Ratcheting ambition to limit warming to $1.5{ }^{\circ} \mathrm{C}$-trade-offs between emission reductions and carbon dioxide removal. Environ. Res. Lett. 2018, 13, 064028. [CrossRef]

130. Griscom, B.W.; Adams, J.; Ellis, P.W.; Houghton, R.A.; Lomax, G.; Miteva, D.A.; Schlesinger, W.H.; Shoch, D.; Siikamäki, J.V.; Smith, P.; et al. Natural climate solutions. Proc. Natl. Acad. Sci. USA 2017, 114, 11645-11650. [CrossRef] [PubMed]

131. Lenton, T.M. The potential for land-based biological $\mathrm{CO}_{2}$ removal to lower future atmospheric $\mathrm{CO}_{2}$ concentration. Carbon Manag. 2010, 1, 145-160. [CrossRef]

132. Huppmann, D.; Kriegler, E.; Krey, V.; Riahi, K.; Rogelj, J.; Rose, S.K.; Weyant, J.; Bauer, N.; Bertram, C.; Bosetti, V.; et al. IAMC $1.5^{\circ} \mathrm{C}$ Scenario Explorer and Data hosted by IIASA; Integrated Assessment Modeling Consortium \& International Institute for Applied Systems Analysis: New York, NY, USA, 2018. [CrossRef]

133. Rogelj, J.; Popp, A.; Calvin, K.V.; Luderer, G.; Emmerling, J.; Gernaat, D.; Fujimori, S.; Strefler, J.; Hasegawa, T.; Marangoni, G.; et al. Scenarios towards limiting global mean temperature increase below $1.5^{\circ} \mathrm{C}$. Nat. Clim. Chang. 2018, 8, 325. [CrossRef]

134. IPCC. Interlinkages between desertification, land degradation, food security and GHG fluxes: Synergies, trade-offs and integrated response options. In Special Report on Climate Change and Land; IPCC: Geneva, Switzerland, 2019.

135. Matovic, D. Biochar as a viable carbon sequestration option: Global and Canadian perspective. Energy 2011, 36, 2011-2016. [CrossRef]

136. Woolf, D.; Lehmann, J.; Lee, D.R. Optimal bioenergy power generation for climate change mitigation with or without carbon sequestration. Nat. Commun. 2016, 7, 13160. [CrossRef]

137. Wang, S.; Dai, G.; Yang, H.; Luo, Z. Lignocellulosic biomass pyrolysis mechanism: A state-of-the-art review. Prog. Energy Combust. Sci. 2017, 62, 33-86. [CrossRef]

138. Kan, T.; Strezov, V.; Evans, T.J. Lignocellulosic biomass pyrolysis: A review of product properties and effects of pyrolysis parameters. Renew. Sustain. Energy Rev. 2016, 57, 126-1140. [CrossRef]

139. Dhyani, V.; Bhaskar, T. A comprehensive review on the pyrolysis of lignocellulosic biomass. Renew. Energy 2018, 129, 695-716. [CrossRef]

140. Spokas, K.A. Review of the stability of biochar in soils: Predictability of O:C molar ratios. Carbon Manag. 2010, 1, 289-303. [CrossRef]

141. McBeath, A.V.; Smernik, R.J.; Krull, E.S.; Lehmann, J. The influence of feedstock and production temperature on biochar carbon chemistry: A solid-state 13C NMR study. Biomass Bioenergy 2014, 60, 121-129. [CrossRef]

142. Leng, L.; Huang, H.; Li, H.; Li, J.; Zhou, W. Biochar stability assessment methods: A review. Sci. Total Environ. 2019, 647, 210-222. [CrossRef] [PubMed]

143. Leng, L.; Huang, H. An overview of the effect of pyrolysis process parameters on biochar stability. Bioresour. Technol. 2018. [CrossRef]

144. Ippolito, J.A.; Spokas, K.A.; Novak, J.; Lentz, R.D.; Cantrell, K.B. Biochar elemental composition and factors influencing nutrient retention. In Biochar for Environmental Management: Science, Technology and Implementation; Routledge: Abingdon, UK, 2015.

145. Li, S.; Harris, S.; Anandhi, A.; Chen, G. Predicting biochar properties and functions based on feedstock and pyrolysis temperature: A review and data syntheses. J. Clean. Prod. 2019, 215, 890-902. [CrossRef]

146. Morales, V.L.; Pérez-Reche, F.J.; Hapca, S.M.; Hanley, K.L.; Lehmann, J.; Zhang, W. Reverse engineering of biochar. Bioresour. Technol. 2015, 183, 163-174. [CrossRef]

147. Sigua, G.C.; Novak, J.M.; Watts, D.W.; Johnson, M.G.; Spokas, K. Efficacies of designer biochars in improving biomass and nutrient uptake of winter wheat grown in a hard setting subsoil layer. Chemosphere 2016, 142, 176-183. [CrossRef] 
148. Buss, W.; Graham, M.C.; Shepherd, J.G.; Mašek, O. Suitability of marginal biomass-derived biochars for soil amendment. Sci. Total Environ. 2016, 547, 314-322. [CrossRef]

149. Domene, X.; Enders, A.; Hanley, K.; Lehmann, J. Ecotoxicological characterization of biochars: Role of feedstock and pyrolysis temperature. Sci. Total Environ. 2015, 512-513, 552-561. [CrossRef]

150. Liu, W.J.; Li, W.W.; Jiang, H.; Yu, H.Q. Fates of Chemical Elements in Biomass during Its Pyrolysis. Chem. Rev. 2017, 117, 6367-6398. [CrossRef]

151. Azzi, E.S.; Karltun, E.; Sundberg, C. Prospective Life Cycle Assessment of Large-Scale Biochar Production and Use for Negative Emissions in Stockholm. Environ. Sci. Technol. 2019, 53, 8466-8476. [CrossRef] [PubMed]

152. Ibarrola, R.; Shackley, S.; Hammond, J. Pyrolysis biochar systems for recovering biodegradable materials: A life cycle carbon assessment. Waste Manag. 2012, 32, 859-868. [CrossRef]

153. Liska, A.J.; Yang, H.; Milner, M.; Goddard, S.; Blanco-Canqui, H.; Pelton, M.P.; Fang, X.X.; Zhu, H.; Suyker, A.E. Biofuels from crop residue can reduce soil carbon and increase $\mathrm{CO}_{2}$ emissions. Nat. Clim. Chang. 2014, 4, 398-401. [CrossRef]

154. Achat, D.L.; Deleuze, C.; Landmann, G.; Pousse, N.; Ranger, J.; Augusto, L. Quantifying consequences of removing harvesting residues on forest soils and tree growth-A meta-analysis. For. Ecol. Manag. 2015, 348, 124-141. [CrossRef]

155. Blanco-Canqui, H.; Lal, R. Crop Residue Removal Impacts on Soil Productivity and Environmental Quality. Crit. Rev. Plant Sci. 2009, 28, 139-163. [CrossRef]

156. Guest, G.; Cherubini, F.; Strømman, A.H. The role of forest residues in the accounting for the global warming potential of bioenergy. GCB Bioenergy 2013, 5, 459-466. [CrossRef]

157. Blanco-Canqui, H. Growing Dedicated Energy Crops on Marginal Lands and Ecosystem Services. Soil Sci. Soc. Am. J. 2016, 80, 845. [CrossRef]

158. Dauber, J.; Jones, M.B.; Stout, J.C. The impact of biomass crop cultivation on temperate biodiversity. GCB Bioenergy 2010, 2, 289-309. [CrossRef]

159. Nijsen, M.; Smeets, E.; Stehfest, E.; Vuuren, D.P. An evaluation of the global potential of bioenergy production on degraded lands. GCB Bioenergy 2012, 4, 130-147. [CrossRef]

160. Patel, M.; Zhang, X.; Kumar, A. Techno-economic and life cycle assessment on lignocellulosic biomass thermochemical conversion technologies: A review. Renew. Sustain. Energy Rev. 2016, 44, 1486-1489. [CrossRef]

161. Tripathi, M.; Sahu, J.N.; Ganesan, P. Effect of process parameters on production of biochar from biomass waste through pyrolysis: A review. Renew. Sustain. Energy Rev. 2016, 55, 467-481. [CrossRef]

162. Neves, D.; Thunman, H.; Matos, A.; Tarelho, L.; Gómez-Barea, A. Characterization and prediction of biomass pyrolysis products. Prog. Energy Combust. Sci. 2011, 37, 611-630. [CrossRef]

163. Demirbas, A.; Arin, G. An Overview of Biomass Pyrolysis. Energy Sources 2002, 24, 471-482. [CrossRef]

164. Sharma, A.; Pareek, V.; Zhang, D. Biomass pyrolysis-A review of modelling, process parameters and catalytic studies. Renew. Sustain. Energy Rev. 2015, 50, 1081-1096. [CrossRef]

165. Bridgwater, A. Review of fast pyrolysis of biomass and product upgrading. Biomass Bioenergy 2012, 38, 68-94. [CrossRef]

166. Sikarwar, V.S.; Zhao, M.; Clough, P.; Yao, J.; Zhong, X.; Memon, M.Z.; Shah, N.; Anthony, E.J.; Fennell, P.S. An overview of advances in biomass gasification. Energy Environ. Sci. 2016, 9, 2939-2977. [CrossRef]

167. You, S.; Ok, Y.S.; Chen, S.S.; Tsang, D.C.; Kwon, E.E.; Lee, J.; Wang, C.H. A critical review on sustainable biochar system through gasification: Energy and environmental applications. Bioresour. Technol. 2017, 246, 242-253. [CrossRef]

168. Mašek, O.; Buss, W.; Brownsort, P.; Rovere, M.; Tagliaferro, A.; Zhao, L.; Cao, X.; Xu, G. Potassium doping increases biochar carbon sequestration potential by $45 \%$, facilitating decoupling of carbon sequestration from soil improvement. Sci. Rep. 2019, 9, 5514. [CrossRef]

169. Wildman, J.; Derbyshire, F. Origins and functions of macroporosity in activated carbons from coal and wood precursors. Fuel 1991, 70, 655-661. [CrossRef]

170. Gray, M.; Johnson, M.G.; Dragila, M.I.; Kleber, M. Water uptake in biochars: The roles of porosity and hydrophobicity. Biomass Bioenergy 2014, 61, 196-205. [CrossRef] 
171. Xiao, X.; Chen, Z.; Chen, B. H/C atomic ratio as a smart linkage between pyrolytic temperatures, aromatic clusters and sorption properties of biochars derived from diverse precursory materials. Sci. Rep. 2016, 6, 22644. [CrossRef] [PubMed]

172. Weber, K.; Quicker, P. Properties of biochar. Fuel 2018, 217, 240-261. [CrossRef]

173. Banik, C.; Lawrinenko, M.; Bakshi, S.; Laird, D.A. Impact of Pyrolysis Temperature and Feedstock on Surface Charge and Functional Group Chemistry of Biochars. J. Environ. Qual. 2018, 47, 452. [CrossRef] [PubMed]

174. Chen, Z.; Xiao, X.; Chen, B.; Zhu, L. Quantification of Chemical States, Dissociation Constants and Contents of Oxygen-containing Groups on the Surface of Biochars Produced at Different Temperatures. Environ. Sci. Technol. 2015, 49, 309-317. [CrossRef]

175. Szymański, G.S.; Karpiński, Z.; Biniak, S.; Światkowski, A. The effect of the gradual thermal decomposition of surface oxygen species on the chemical and catalytic properties of oxidized activated carbon. Carbon 2002, 40, 2627-2639. [CrossRef]

176. Mia, S.; Dijkstra, F.A.; Singh, B. Aging Induced Changes in Biochar's Functionality and Adsorption Behavior for Phosphate and Ammonium. Environ. Sci. Technol. 2017, 51, 8359-8367. [CrossRef]

177. Lawrinenko, M.; Jing, D.; Banik, C.; Laird, D.A. Aluminum and iron biomass pretreatment impacts on biochar anion exchange capacity. Carbon 2017, 118, 422-430. [CrossRef]

178. Lawrinenko, M.; Laird, D.A. Anion exchange capacity of biochar. Green Chem. 2015, 17, 4628-4636. [CrossRef]

179. Lawrinenko, M.; Laird, D.A.; Johnson, R.L.; Jing, D. Accelerated aging of biochars: Impact on anion exchange capacity. Carbon 2016, 103, 217-227. [CrossRef]

180. Klüpfel, L.; Keiluweit, M.; Kleber, M.; Sander, M. Redox Properties of Plant Biomass-Derived Black Carbon (Biochar). Environ. Sci. Technol. 2014, 48, 5601-5611. [CrossRef]

181. Joseph, S.; Husson, O.; Graber, E.; van Zwieten, L.; Taherymoosavi, S.; Thomas, T.; Nielsen, S.; Ye, J.; Pan, G.; Chia, C.; et al. The Electrochemical Properties of Biochars and How They Affect Soil Redox Properties and Processes. Agronomy 2015, 5, 322-340. [CrossRef]

182. Pinheiro Pires, A.P.; Arauzo, J.; Fonts, I.; Domine, M.E.; Fernández Arroyo, A.; Garcia-Perez, M.E.; Montoya, J.; Chejne, F.; Pfromm, P.; Garcia-Perez, M. Challenges and Opportunities for Bio-oil Refining: A Review. Energy Fuels 2019, 33, 4683-4720. [CrossRef]

183. Iordan, C.M.; Hu, X.; Arvesen, A.; Kauppi, P.; Cherubini, F. Contribution of forest wood products to negative emissions: Historical comparative analysis from 1960 to 2015 in Norway, Sweden and Finland. Carbon Balance Manag. 2018, 13, 12. [CrossRef] [PubMed]

184. Crombie, K.; Mašek, O. Pyrolysis biochar systems, balance between bioenergy and carbon sequestration. GCB Bioenergy 2015, 7, 349-361. [CrossRef]

185. Crombie, K.; Mašek, O. Investigating the potential for a self-sustaining slow pyrolysis system under varying operating conditions. Bioresour. Technol. 2014, 162, 148-156. [CrossRef]

186. Chidikofan, G.; Benoist, A.; Sawadogo, M.; Volle, G.; Valette, J.; Coulibaly, Y.; Pailhes, J.; Pinta, F. Assessment of Environmental Impacts of Tar Releases from a Biomass Gasifier Power Plant for Decentralized Electricity Generation. Energy Procedia 2017, 118, 158-163. [CrossRef]

187. Leijenhorst, E.J.; Wolters, W.; Van De Beld, L.; Prins, W. Inorganic element transfer from biomass to fast pyrolysis oil: Review and experiments. Fuel Process. Technol. 2016, 149, 96-111. [CrossRef]

188. Zimmerman, A.R. Abiotic and Microbial Oxidation of Laboratory-Produced Black Carbon (Biochar). J. Environ. Sci. 2010, 44, 1295-1301. [CrossRef]

189. Lehmann, J.; Abiven, S.; Kleber, M.; Pan, G.; Singh, B.P.; Sohi, S.P.; Zimmerman, A.R. Persistence of biochar in soil. In Biochar for Environmental Management-Science, Technology and Implementation; Lehmann, J., Joseph, S., Eds.; Routledge: Abingdon, UK, 2015; pp. 62-88.

190. Yang, F.; Xu, Z.; Yu, L.; Gao, B.; Xu, X.; Zhao, L.; Cao, X. Kaolinite Enhances the Stability of the Dissolvable and Undissolvable Fractions of Biochar via Different Mechanisms. Environ. Sci. Technol. 2018, 52, 8321-8329. [CrossRef]

191. Yang, F.; Zhao, L.; Gao, B.; Xu, X.; Cao, X. The Interfacial Behavior between Biochar and Soil Minerals and Its Effect on Biochar Stability. Environ. Sci. Technol. 2016, 50, 2264-2271. [CrossRef]

192. Liu, C.H.; Chu, W.; Li, H.; Boyd, S.A.; Teppen, B.J.; Mao, J.; Lehmann, J.; Zhang, W. Quantification and characterization of dissolved organic carbon from biochars. Geoderma 2019, 335, 161-169. [CrossRef] 
193. Ward, C.P.; Sleighter, R.L.; Hatcher, P.G.; Cory, R.M. Insights into the complete and partial photooxidation of black carbon in surface waters. Environ. Sci. Process. Impacts 2014, 16, 721-731. [CrossRef] [PubMed]

194. Santín, C.; Doerr, S.H.; Merino, A.; Bucheli, T.D.; Bryant, R.; Ascough, P.; Gao, X.; Masiello, C.A. Carbon sequestration potential and physicochemical properties differ between wildfire charcoals and slow-pyrolysis biochars. Sci. Rep. 2017, 7, 11233. [CrossRef] [PubMed]

195. DeCiucies, S.; Whitman, T.; Woolf, D.; Enders, A.; Lehmann, J. Priming mechanisms with additions of pyrogenic organic matter to soil. Geochim. Cosmochim. Acta 2018, 238, 329-342. [CrossRef]

196. Kerré, B.; Bravo, C.; Leifeld, J.; Cornelissen, G.; Smolders, E. Historical soil amendment with charcoal increases sequestration of non-charcoal carbon: A comparison among methods of black carbon quantification. Eur. J. Soil Sci. 2016, 67, 324-331. [CrossRef]

197. Hernandez-Soriano, M.C.; Kerré, B.; Kopittke, P.M.; Horemans, B.; Smolders, E. Biochar affects carbon composition and stability in soil: A combined spectroscopy-microscopy study. Sci. Rep. 2016, 6, 25127. [CrossRef]

198. Kerré, B.; Willaert, B.; Smolders, E. Lower residue decomposition in historically charcoal-enriched soils is related to increased adsorption of organic matter. Soil Biology Biochem. 2017, 104, 1-7. [CrossRef]

199. Liu, S.; Zhang, Y.; Zong, Y.; Hu, Z.; Wu, S.; Zhou, J.; Jin, Y.; Zou, J. Response of soil carbon dioxide fluxes, soil organic carbon and microbial biomass carbon to biochar amendment: A Meta-analysis. GCB Bioenergy 2016, 8, 392-406. [CrossRef]

200. Xiang, Y.; Deng, Q.; Duan, H.; Guo, Y. Effects of biochar application on root traits: A meta-analysis. GCB Bioenergy 2017, 9, 1563-1572. [CrossRef]

201. Hernandez-Soriano, M.C.; Kerré, B.; Goos, P.; Hardy, B.; Dufey, J.; Smolders, E. Long-term effect of biochar on the stabilization of recent carbon: Soils with historical inputs of charcoal. GCB Bioenergy 2016, 8, 371-381. [CrossRef]

202. Borchard, N.; Ladd, B.; Eschemann, S.; Hegenberg, D.; Möseler, B.M.; Amelung, W. Black carbon and soil properties at historical charcoal production sites in Germany. Geoderma 2014, 232-234, 236-242. [CrossRef]

203. Weng, Z.; Van Zwieten, L.; Singh, B.P.; Tavakkoli, E.; Joseph, S.; Macdonald, L.M.; Rose, T.J.; Rose, M.T.; Kimber, S.W.L.; Morris, S.; et al. Biochar built soil carbon over a decade by stabilizing rhizodeposits. Nat. Clim. Chang. 2017, 7, 371-376. [CrossRef]

204. Hardy, B.; Cornelis, J.T.; Houben, D.; Leifeld, J.; Lambert, R.; Dufey, J.E. Evaluation of the long-term effect of biochar on properties of temperate agricultural soil at pre-industrial charcoal kiln sites in Wallonia, Belgium. Eur. J. Soil Sci. 2017, 68, 80-89. [CrossRef]

205. Dong, X.; Singh, B.P.; Li, G.; Lin, Q.; Zhao, X. Biochar increased field soil inorganic carbon content five years after application. Soil Tillage Res. 2019, 186, 36-41. [CrossRef]

206. Saunois, M.; Bousquet, P.; Poulter, B.; Peregon, A.; Ciais, P.; Canadell, J.G.; Dlugokencky, E.J.; Etiope, G.; Bastviken, D.; Houweling, S.; et al. The global methane budget 2000-2012. Earth Syst. Sci. Data 2016, 8, 697-751. [CrossRef]

207. Silva, F.C.; Borrego, C.; Keizer, J.J.; Amorim, J.H.; Verheijen, F.G.A. Effects of moisture content on wind erosion thresholds of biochar. Atmos. Environ. 2015, 123, 121-128. [CrossRef]

208. Padhye, L.P. Influence of surface chemistry of carbon materials on their interactions with inorganic nitrogen contaminants in soil and water. Chemosphere 2017, 184, 532-547. [CrossRef]

209. Nguyen, T.T.N.; Xu, C.Y.; Tahmasbian, I.; Che, R.; Xu, Z.; Zhou, X.; Wallace, H.M.; Bai, S.H. Effects of biochar on soil available inorganic nitrogen: A review and meta-analysis. Geoderma 2017, 288, 79-96. [CrossRef]

210. Joseph, S.; Kammann, C.I.; Shepherd, J.G.; Conte, P.; Schmidt, H.P.; Hagemann, N.; Rich, A.M.; Marjo, C.E.; Allen, J.; Munroe, P.; et al. Microstructural and associated chemical changes during the composting of a high temperature biochar: Mechanisms for nitrate, phosphate and other nutrient retention and release. Sci. Total Environ. 2018, 618, 1210-1223. [CrossRef]

211. Hussain, M.; Farooq, M.; Nawaz, A.; Al-Sadi, A.M.; Solaiman, Z.M.; Alghamdi, S.S.; Ammara, U.; Ok, Y.S.; Siddique, K.H.M. Biochar for crop production: Potential benefits and risks. J. Soils Sediments 2017, 17, 685-716. [CrossRef]

212. Nelissen, V.; Saha, B.K.; Ruysschaert, G.; Boeckx, P. Effect of different biochar and fertilizer types on $\mathrm{N}_{2} \mathrm{O}$ and NO emissions. Soil Biology Biochem. 2014, 70, 244-255. [CrossRef]

213. Obia, A.; Cornelissen, G.; Mulder, J.; Dörsch, P. Effect of Soil pH Increase by Biochar on $\mathrm{NO}, \mathrm{N}_{2} \mathrm{O}$ and $\mathrm{N}_{2}$ Production during Denitrification in Acid Soils. PLoS ONE 2015, 10, e0138781. [CrossRef] [PubMed] 
214. Fan, C.; Chen, H.; Li, B.; Xiong, Z. Biochar reduces yield-scaled emissions of reactive nitrogen gases from vegetable soils across China. Biogeosciences 2017, 14, 2851-2863. [CrossRef]

215. Niu, Y.; Luo, J.; Liu, D.; Müller, C.; Zaman, M.; Lindsey, S.; Ding, W. Effect of biochar and nitrapyrin on nitrous oxide and nitric oxide emissions from a sandy loam soil cropped to maize. Biology Fertil. Soils 2018, 54, 645-658. [CrossRef]

216. Glaser, B.; Lehr, V.I. Biochar effects on phosphorus availability in agricultural soils: A meta-analysis. Sci. Rep. 2019, 9, 9338. [CrossRef] [PubMed]

217. Laird, D.; Rogovska, N. Biocahr effects on nutrient leaching. In Biochar for Environmental Management: Science, Technology and Implementation; Routledge: Abingdon, UK, 2015.

218. Kinney, T.; Masiello, C.; Dugan, B.; Hockaday, W.; Dean, M.; Zygourakis, K.; Barnes, R. Hydrologic properties of biochars produced at different temperatures. Biomass Bioenergy 2012, 41, 34-43. [CrossRef]

219. Sun, F.; Lu, S. Biochars improve aggregate stability, water retention, and pore-space properties of clayey soil. J. Plant Nutr. Soil Sci. 2014, 177, 26-33. [CrossRef]

220. Trifunovic, B.; Gonzales, H.B.; Ravi, S.; Sharratt, B.S.; Mohanty, S.K. Dynamic effects of biochar concentration and particle size on hydraulic properties of sand. Land Degrad. Dev. 2018, 29, 884-893. [CrossRef]

221. Hallin, I.L.; Douglas, P.; Doerr, S.H.; Bryant, R. The effect of addition of a wettable biochar on soil water repellency. Eur. J. Soil Sci. 2015, 66, 1063-1073. [CrossRef]

222. Liu, Z.; Dugan, B.; Masiello, C.A.; Gonnermann, H.M. Biochar particle size, shape, and porosity act together to influence soil water properties. PLoS ONE 2017, 12, e0179079. [CrossRef]

223. Liu, Z.; Xu, J.; Li, X.; Wang, J. Mechanisms of biochar effects on thermal properties of red soil in south China. Geoderma 2018, 323, 41-51. [CrossRef]

224. Usowicz, B.; Lipiec, J.; Lukowski, M.; Marczewski, W.; Usowicz, J. The effect of biochar application on thermal properties and albedo of loess soil under grassland and fallow. Soil Tillage Res. 2016, 164, 45-51. [CrossRef]

225. Zhang, Y.; Hu, X.; Zou, J.; Zhang, D.; Chen, W.; Liu, Y.; Chen, Y.; Wang, X. Response of surface albedo and soil carbon dioxide fluxes to biochar amendment in farmland. J. Soils Sediments 2018, 18, 1590-1601. [CrossRef]

226. Yan, Q.; Dong, F.; Li, J.; Duan, Z.; Yang, F.; Li, X.; Lu, J.; Li, F. Effects of maize straw-derived biochar application on soil temperature, water conditions and growth of winter wheat. Eur. J. Soil Sci. 2019, [CrossRef]

227. Zhang, Q.; Wang, Y.; Wu, Y.; Wang, X.; Du, Z.; Liu, X.; Song, J. Effects of Biochar Amendment on Soil Thermal Conductivity, Reflectance, and Temperature. Soil Sci. Soc. Am. J. 2013, 77, 1478. [CrossRef]

228. Verheijen, F.G.A.; Jeffery, S.; van der Velde, M.; Penížek, V.; Beland, M.; Bastos, A.C.; Keizer, J.J. Reductions in soil surface albedo as a function of biochar application rate: Implications for global radiative forcing. Environ. Res. Lett. 2013, 8, 044008. [CrossRef]

229. Wang, T.; Stewart, C.E.; Sun, C.; Wang, Y.; Zheng, J. Effects of biochar addition on evaporation in the five typical Loess Plateau soils. CATENA 2018, 162, 29-39. [CrossRef]

230. Koide, R.T.; Nguyen, B.T.; Skinner, R.H.; Dell, C.J.; Peoples, M.S.; Adler, P.R.; Drohan, P.J. Biochar amendment of soil improves resilience to climate change. GCB Bioenergy 2015, 7, 1084-1091. [CrossRef]

231. Hammond, J.; Shackley, S.; Sohi, S.; Brownsort, P. Prospective life cycle carbon abatement for pyrolysis biochar systems in the UK. Energy Policy 2011, 39, 2646-2655. [CrossRef]

232. Wang, Z.; Dunn, J.B.; Han, J.; Wang, M.Q. Effects of co-produced biochar on life cycle greenhouse gas emissions of pyrolysis-derived renewable fuels. Biofuels Bioprod. Biorefining 2014, 8, 189-204. [CrossRef]

233. Field, J.L.; Keske, C.M.H.; Birch, G.L.; DeFoort, M.W.; Cotrufo, M.F. Distributed biochar and bioenergy coproduction: A regionally specific case study of environmental benefits and economic impacts. GCB Bioenergy 2013, 5, 177-191. [CrossRef]

234. Bartocci, P.; Bidini, G.; Saputo, P.; Fantozzi, F. Biochar pellet carbon footprint. Chem. Eng. Trans. 2016, 50, 217-222. [CrossRef]

235. Tadele, D.; Roy, P.; Defersha, F.; Misra, M.; Mohanty, A.K. Life Cycle Assessment of renewable filler material (biochar) produced from perennial grass (Miscanthus). AIMS Energy 2019, 7, 430. [CrossRef]

236. Clare, A.; Shackley, S.; Joseph, S.; Hammond, J.; Pan, G.; Bloom, A. Competing uses for China's straw: The economic and carbon abatement potential of biochar. GCB Bioenergy 2015, 7, 1272-1282. [CrossRef] 
237. Rajabi Hamedani, S.; Kuppens, T.; Malina, R.; Bocci, E.; Colantoni, A.; Villarini, M. Life Cycle Assessment and Environmental Valuation of Biochar Production: Two Case Studies in Belgium. Energies 2019, 12, 2166. [CrossRef]

238. Muñoz, E.; Curaqueo, G.; Cea, M.; Vera, L.; Navia, R. Environmental hotspots in the life cycle of a biochar-soil system. J. Clean. Prod. 2017, 158, 1-7. [CrossRef]

239. Llorach-Massana, P.; Lopez-Capel, E.; Peña, J.; Rieradevall, J.; Montero, J.I.; Puy, N. Technical feasibility and carbon footprint of biochar co-production with tomato plant residue. Waste Manag. 2017, 67, 121-130. [CrossRef]

240. Robb, S.; Dargusch, P. A financial analysis and life-cycle carbon emissions assessment of oil palm waste biochar exports from Indonesia for use in Australian broad-acre agriculture. Carbon Manag. 2018, 9, 105-114. [CrossRef]

241. Peters, J.F.; Iribarren, D.; Dufour, J. Biomass Pyrolysis for Biochar or Energy Applications? A Life Cycle Assessment. Environ. Sci. Technol. 2015, 49, 5195-5202. [CrossRef]

242. Homagain, K.; Shahi, C.; Luckai, N.; Sharma, M. Life cycle environmental impact assessment of biochar-based bioenergy production and utilization in Northwestern Ontario, Canada. J. For. Res. 2015, 26, 799-809. [CrossRef]

243. Thornley, P.; Gilbert, P.; Shackley, S.; Hammond, J. Maximizing the greenhouse gas reductions from biomass: The role of life cycle assessment. Biomass Bioenergy 2015, 81, 35-43. [CrossRef]

244. Mohammadi, A.; Sandberg, M.; Venkatesh, G.; Eskandari, S.; Dalgaard, T.; Joseph, S.; Granström, K. Environmental analysis of producing biochar and energy recovery from pulp and paper mill biosludge. J. Ind. Ecol. 2019. [CrossRef]

245. Mohammadi, A.; Sandberg, M.; Venkatesh, G.; Eskandari, S.; Dalgaard, T.; Joseph, S.; Granström, K. Environmental performance of end-of-life handling alternatives for paper-and-pulp-mill sludge: Using digestate as a source of energy or for biochar production. Energy 2019, 182, 594-605. [CrossRef]

246. Cao, Y.; Pawlowski, A. Life cycle assessment of two emerging sewage sludge-to-energy systems: Evaluating energy and greenhouse gas emissions implications. Bioresour. Technol. 2013, 127, 81-91. [CrossRef]

247. Lu, H.R.; El Hanandeh, A. Life cycle perspective of bio-oil and biochar production from hardwood biomass; what is the optimum mix and what to do with it? J. Clean. Prod. 2019, 212, 173-189. [CrossRef]

248. Miller-Robbie, L.; Ulrich, B.A.; Ramey, D.F.; Spencer, K.S.; Herzog, S.P.; Cath, T.Y.; Stokes, J.R.; Higgins, C.P. Life cycle energy and greenhouse gas assessment of the co-production of biosolids and biochar for land application. J. Clean. Prod. 2015, 91, 118-127. [CrossRef]

249. Thers, H.; Djomo, S.N.; Elsgaard, L.; Knudsen, M.T. Biochar potentially mitigates greenhouse gas emissions from cultivation of oilseed rape for biodiesel. Sci. Total Environ. 2019, 671, 180-188. [CrossRef]

250. Uusitalo, V.; Leino, M. Neutralizing global warming impacts of crop production using biochar from side flows and buffer zones: A case study of oat production in the boreal climate zone. J. Clean. Prod. 2019, 227, 48-57. [CrossRef]

251. Mohammadi, A.; Cowie, A.; Anh Mai, T.L.; de la Rosa, R.A.; Kristiansen, P.; Brandão, M.; Joseph, S. Biochar use for climate-change mitigation in rice cropping systems. J. Clean. Prod. 2016, 116, 61-70. [CrossRef]

252. Xu, X.; Cheng, K.; Wu, H.; Sun, J.; Yue, Q.; Pan, G. Greenhouse gas mitigation potential in crop production with biochar soil amendment-A carbon footprint assessment for cross-site field experiments from China. GCB Bioenergy 2019, 11, 592-605. [CrossRef]

253. Ericsson, N.; Sundberg, C.; Nordberg, Å.; Ahlgren, S.; Hansson, P.A. Time-dependent climate impact and energy efficiency of combined heat and power production from short-rotation coppice willow using pyrolysis or direct combustion. GCB Bioenergy 2017, 9, 876-890. [CrossRef]

254. Lugato, E.; Vaccari, F.P.; Genesio, L.; Baronti, S.; Pozzi, A.; Rack, M.; Woods, J.; Simonetti, G.; Montanarella, L.; Miglietta, F. An energy-biochar chain involving biomass gasification and rice cultivation in Northern Italy. GCB Bioenergy 2013, 5, 192-201. [CrossRef]

255. Barry, D.; Barbiero, C.; Briens, C.; Berruti, F. Pyrolysis as an economical and ecological treatment option for municipal sewage sludge. Biomass Bioenergy 2019, 122, 472-480. [CrossRef]

256. Nguyen, T.L.T.; Hermansen, J.E.; Nielsen, R.G. Environmental assessment of gasification technology for biomass conversion to energy in comparison with other alternatives: The case of wheat straw. J. Clean. Prod. 2013, 53, 138-148. [CrossRef] 
257. Sparrevik, M.; Field, J.L.; Martinsen, V.; Breedveld, G.D.; Cornelissen, G. Life cycle assessment to evaluate the environmental impact of biochar implementation in conservation agriculture in Zambia. Environ. Sci. Technol. 2013, 47, 1206-1215. [CrossRef]

258. Sparrevik, M.; Lindhjem, H.; Andria, V.; Fet, A.M.; Cornelissen, G. Environmental and socioeconomic impacts of utilizing waste for biochar in rural areas in indonesia-a systems perspective. Environ. Sci. Technol. 2014, 48, 4664-4671. [CrossRef]

259. Smebye, A.B.; Sparrevik, M.; Schmidt, H.P.; Cornelissen, G. Life-cycle assessment of biochar production systems in tropical rural areas: Comparing flame curtain kilns to other production methods. Biomass Bioenergy 2017, 101, 35-43. [CrossRef]

260. Schmidt, T.; Fernando, A.L.; Monti, A.; Rettenmaier, N. Life Cycle Assessment of Bioenergy and Bio-Based Products from Perennial Grasses Cultivated on Marginal Land in the Mediterranean Region. BioEnergy Res. 2015, 8, 1548-1561. [CrossRef]

261. Brandão, M.; Levasseur, A.; Kirschbaum, M.U.F.; Weidema, B.P.; Cowie, A.L.; Jørgensen, S.V.; Hauschild, M.Z.; Pennington, D.W.; Chomkhamsri, K. Key issues and options in accounting for carbon sequestration and temporary storage in life cycle assessment and carbon footprinting. Int. J. Life Cycle Assess. 2013, 18, 230-240. [CrossRef]

262. Cherubini, F.; Peters, G.P.; Berntsen, T.; Strømman, A.H.; Hertwich, E. $\mathrm{CO}_{2}$ emissions from biomass combustion for bioenergy: Atmospheric decay and contribution to global warming. GCB Bioenergy 2011, 3, 413-426. [CrossRef]

263. Bright, R.M. Metrics for Biogeophysical Climate Forcings from Land Use and Land Cover Changes and Their Inclusion in Life Cycle Assessment: A Critical Review. Environ. Sci. Technol. 2015, 49, 3291-3303. [CrossRef] [PubMed]

264. Cherubini, F.; Fuglestvedt, J.; Gasser, T.; Reisinger, A.; Cavalett, O.; Huijbregts, M.A.J.; Johansson, D.J.A.; Jørgensen, S.V.; Raugei, M.; Schivley, G.; et al. Bridging the gap between impact assessment methods and climate science. Environ. Sci. Policy 2016, 64, 129-140. [CrossRef]

265. Caiazzo, F.; Malina, R.; Staples, M.D.; Wolfe, P.J.; Yim, S.H.L.; Barrett, S.R.H. Quantifying the climate impacts of albedo changes due to biofuel production: A comparison with biogeochemical effects. Environ. Res. Lett. 2014, 9, 024015. [CrossRef]

266. Georgescu, M.; Lobell, D.B.; Field, C.B. Direct climate effects of perennial bioenergy crops in the United States. Proc. Natl. Acad. Sci. USA 2011, 108, 4307-4312. [CrossRef]

267. Arvesen, A.; Cherubini, F.; Serrano, G.d.A.; Astrup, R.; Becidan, M.; Belbo, H.; Goile, F.; Grytli, T.; Guest, G.; Lausselet, $\mathrm{C}$.; et al. Cooling aerosols and changes in albedo counteract warming from $\mathrm{CO}_{2}$ and black carbon from forest bioenergy in Norway. Sci. Rep. 2018, 8, 3299. [CrossRef]

268. Preston, C.J. Ethics and geoengineering: Reviewing the moral issues raised by solar radiation management and carbon dioxide removal. WIREs Clim. Chang. 2013, 4, 23-37. [CrossRef]

269. Curtis, P.G.; Slay, C.M.; Harris, N.L.; Tyukavina, A.; Hansen, M.C. Classifying drivers of global forest loss. Science 2018, 361, 1108-1111. [CrossRef]

270. Jeffery, S.; Verheijen, F.G.; Bastos, A.C.; Van Der Velde, M. A comment on 'Biochar and its effects on plant productivity and nutrient cycling: A meta-analysis': On the importance of accurate reporting in supporting a fast-moving research field with policy implications. GCB Bioenergy 2014, 6, 176-179. [CrossRef]

271. Harpole, W.S.; Biederman, L.A. On the importance of accurate reporting: A response to comments on 'Biochar and its effects on plant productivity and nutrient cycling: A meta-analysis'. GCB Bioenergy 2014, 6, 172-175. [CrossRef]

(C) 2019 by the authors. Licensee MDPI, Basel, Switzerland. This article is an open access article distributed under the terms and conditions of the Creative Commons Attribution (CC BY) license (http://creativecommons.org/licenses/by/4.0/). 